\title{
The use of cultural memory in reinforcing contemporary Russian patriotism: A case study of the film "Stalingrad" (2013)
}

Laura Roop

Follow this and additional works at: https://researchrepository.wvu.edu/etd

\section{Recommended Citation}

Roop, Laura, "The use of cultural memory in reinforcing contemporary Russian patriotism: A case study of the film "Stalingrad" (2013)" (2015). Graduate Theses, Dissertations, and Problem Reports. 6530.

https://researchrepository.wvu.edu/etd/6530

This Thesis is protected by copyright and/or related rights. It has been brought to you by the The Research Repository @ WVU with permission from the rights-holder(s). You are free to use this Thesis in any way that is permitted by the copyright and related rights legislation that applies to your use. For other uses you must obtain permission from the rights-holder(s) directly, unless additional rights are indicated by a Creative Commons license in the record and/ or on the work itself. This Thesis has been accepted for inclusion in WVU Graduate Theses, Dissertations, and Problem Reports collection by an authorized administrator of The Research Repository @ WVU. For more information, please contact researchrepository@mail.wvu.edu. 


\title{
THE USE OF CULTURAL MEMORY IN REINFORCING \\ CONTEMPORARY RUSSIAN PATRIOTISM: A CASE STUDY OF THE \\ FILM STALINGRAD (2013)
}

\author{
Laura Roop \\ Thesis submitted to the \\ Eberly College of Arts and Sciences \\ at West Virginia University \\ in partial fulfillment of the requirements \\ for the degree of
}

Master of Arts in History

Robert E. Blobaum, PhD., Chair

Katherine B. Aaslestad, PhD.

Joshua Arthurs, PhD.

Department of History

Morgantown, West Virginia

2015

Keywords: Cultural Memory, Patriotism, Russian Cinema, Stalingrad, WW II Copyright 2015 Laura Roop 


\begin{abstract}
The Use of Cultural Memory in Reinforcing Contemporary Russian Patriotism: A Case Study of the Film Stalingrad (2013)
\end{abstract}

Laura Roop

According to cultural memory theory, cultural tools such as texts and symbols transmit the knowledge of meaningful historical events to groups. These cultural tools reproduce history by cultivating narratives that are relevant in a given time, and thus reflect the ongoing concerns over memory. The purpose of communicating significant turning points in a nation's history is to create a system of values, a self-image and the continuity of a nation. Films are considered to be both textual and visual representations of cultural memory. Since memory and commemoration of the Second World War have gone through many changes, one has to analyze how cultural memory has influenced the portrayal as well as the reception of the event. The aim of this master's thesis is to bring out what kind of narratives and symbols are used in the film Stalingrad, which was produced in 2013, in order to foster patriotism in contemporary Russia. Stalingrad, directed by Fyodor Bondarchuk, with screenplay by Ilya Tilkin and Sergey Snezhkin, is the all-time highest-grossing war feature film in Russia that portrays the Battle of Stalingrad.

Discourse analysis is chosen as method of the research, which will incorporate narrative analysis, intertextual analysis and iconographic analysis. The research reveals that Stalingrad influences cultural memory by using new technology, music, simple plot and by creating emotional attachment to characters. By applying four main narratives that are products of the wartime portrayal of the Second World War, but which have their roots in the pre-Soviet Russian culture - "a holy war" "a war to save the motherland," "a war to save Russian civilization," and "a battle to the death" - the film reinforces patriotism. The continuity of the Russian state and the connection with Old Russian culture is transmitted in the film through the use of Orthodox symbols and intertextuality with previous war films and literature. Stalingrad's dialogue with Western films contests various narratives; on the other hand it justifies Russian patriotism by showing that it does not differ from American patriotism. 


\section{ACKNOWLEDGMENTS}

Foremost, I would like to express my sincere gratitude to my supervisors Prof. Robert Blobaum and Dr. Heiko Pääbo for their guidance, patience and motivation. They provided an excellent atmosphere for writing my thesis and helped me to develop my research by giving me ideas and feedback. I am also grateful to them for giving me the opportunity to study in the United States in the framework of Atlantis programme that enriched my life with new knowledge and new people.

Besides my supervisors, I would like to thank the rest of my professors at West Virginia University: Prof. Katherine Aaslestad, Prof. Joshua Arthurs, Prof. Mark Tauger and Dr. Donata Blobaum, for the exciting and useful discussions in their classes as well as interesting course materials. I am very grateful for the guidance and support from their side throughout the year in the United States, for the interesting conversations, and for the ideas and suggestions they gave.

I want to thank my friend and colleague Ms Olga Bogdanova for her encouragement, insightful comments and the time she has dedicated to discussing my research. My gratitude goes also to all the rest of my colleagues at the European College of the University of Tartu for keeping up my motivation and giving me strength during this process.

I am grateful that I have supportive family and so many good friends, who never let me down and are always there for me. I would not have completed the thesis without their help. 


\section{TABLE OF CONTENTS}

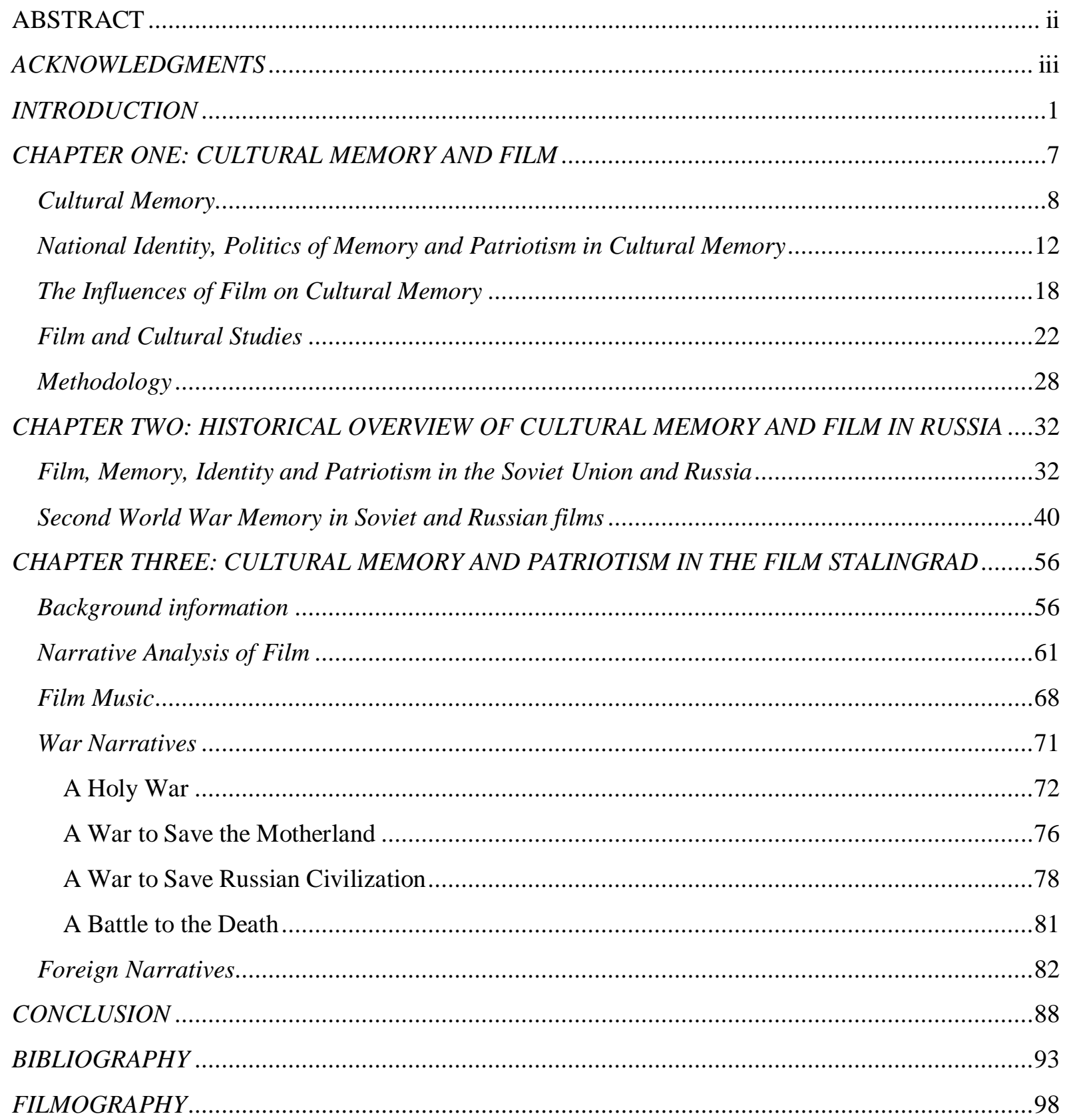




\section{INTRODUCTION}

The memory of the Second World War is used in the contemporary Russian media as a unifying and motivating event for the nation. ${ }^{1}$ For instance, the current conflict between Ukraine and Russia is fuelled by the various references to the Second World War; the Russian mass media, among others, presents Ukrainians as fascists, pointing out that the Ukrainian politicians are insulting the memory of the Great Patriotic War. ${ }^{2}$ The supporters of Russia in eastern Ukraine, for their part, are carrying signs such as "Glory to the heroes of the Second World War." ${ }^{3}$ Furthermore, Crimea itself serves as a symbol: it reminds of the strong resistance to the Nazis in the beginning of the Second World War as well as "protecting their own" in the Crimean War. ${ }^{4}$ This illustrates that the memory of the war is still used both in internal and foreign affairs to make distinctions between good and bad, friends and enemies. In addition, the event is perceived as "sacred" and media plays on emotions to involve people in the public debates.

From the beginning of Putin's rule, the memory of the Second World War has served as a tool for the Russian nation-building process: it strengthens patriotism and creates a unifying Russian identity. The war plays a double function; on the one hand it celebrates the victory over the invaders, on the other hand it commemorates those who sacrificed their lives for their motherland. Although one can see the continuation of the Soviet myth of the Great

\footnotetext{
${ }^{1}$ Marko Lehti and David J. Smith, eds., Post-Cold War Identity Politics: Northern and Baltic Experiences (London: Routledge, 2004), 233; Stephen M. Norris, Blockbuster History in the New Russia : Movies, Memory, and Patriotism (Bloomington, IN: Indiana University Press, 2012), 11.

2 "На Заседании Совбеза Украинский Чиновник Оскорбил Память Жертв Второй Мировой (In English: At the Security Council Meeting a Ukrainian Official Insulted the Memory of the Second World War Victims)," Vesti, March 4, 2014, http://www.vesti.ru/doc.html?id=1345803.

3“'Харьков, Донецк и Одесса Поднимают Российские Флаги (In English: Harkhov, Donetsk, Odessa are Raising Russian Flags)," Vesti, March 3, 2014, http://www.vesti.ru/doc.html?id=1342664.

${ }^{4}$ Maartje Abbenhuis, An Age of Neutrals: Great Power Politics, 1815-1914 (Cambridge: Cambridge University Press, 2014), 69.
} 
Patriotic War, it is important to acknowledge that the interpretation of the war as well as its commemoration have gone through many changes during the postwar era. In the Soviet period, there was first an emphasis on Stalin as the leader who led the nation to the heroic victory. Over time, his role decreased, and instead Zhukov, Brezhnev and the Communist Party took credit for the victory and the celebrations of the war became institutionalized. Nowadays, the Orthodox Church occupies a central position in the commemoration of the war, replacing the communist ideology with religious images and symbols. Celebrations and commemorations are one way the state can enforce its own interpretation on people. Popular pressure, however, can also make demands and the state has to acknowledge the importance of particular events, since they are deeply rooted in people's consciousness. For instance, developments in the post-Soviet Russian Federation demonstrated early on that even if the authorities wished to cancel the celebrations of the Second World War, they had to change their minds because of the fear of losing popular support. ${ }^{5}$

In order to understand why the Second World War, as the greatest achievement of the Soviet Union, is promoted by the Russian state nowadays, one has to look at the war from the perspective of cultural memory. The Second World War is a "fixed point," an event, whose memory has been preserved by cultural tools and institutional communication for several decades. ${ }^{6}$ There are numerous documentary footages, photos, paintings, history textbooks, literary books and films that portray the war, and thus can be seen as products and agents of cultural memory. These cultural tools transmit knowledge of the event to the nation, and tell the story of the greatest achievement through narratives that reflect the time they were created and received. Although the memory of the Second World War is constantly transformed over

\footnotetext{
${ }^{5}$ Lehti and Smith, Post-Cold War Identity Politics, 233; Nina Turmakin, "Myth and Memory in Soviet Society," Society 24, no. 6 (1987): 69; Zhan T. Toshchenko, "Historical Consciousness and Historical Memory: An Analysis of the Current Situation," Russian Studies in History 49, no. 1 (Summer 2010): 41; Sergei Kudryashov, "Remembering and Researching the War: The Soviet and Russian Experience," in Experience and Memory: The Second World War in Europe (New York, Oxford: Berghahn, 2010), 86-97.

${ }^{6}$ See more: Jan Assmann, "Collective Memory and Cultural Identity," New German Critique, no. 65 (1995): 129.
} 
the time the stories are told, the importance of the event stays the same: it is still the event that makes distinctions between "us" and "them" and proclaims victory over the invaders.

Kilbourn states that nowadays "memory derives its primary meaning, its existence as such, from visually based technologies like cinema." ${ }^{77}$ Film is considered to be an effective agent of cultural memory, because it influences the perception of the past and helps people to remember. ${ }^{8}$ For instance, polls taken in Russia in 2002 ("Historical memory of the Russian population") by Egorov et al. and in 2005 ("The war in historical memory of Russians") by Afanasieva and Merkushin demonstrated that people learn most about history in school; however, films took second place. ${ }^{9}$ Hence, film is a very important source of information about history in Russia. On the basis of this information, a notion of shared past is constructed, which in turn unites a nation and shapes its identity. ${ }^{10}$ Through offering portraits of heroic achievements and fateful events, film also communicates a nation's values, mission and loyalty to the state; thus it has the potential to foster patriotism.

Popular film is an especially effective tool in communicating shared past to communities, because it reaches large audiences, visualizes the story, is interesting and catchy, and can be replayed. Story and technology allow people to get information about the past easily without doing much independent work; therefore, film is considered much more influential in creating a unifying identity than textbooks or novels. ${ }^{11}$ The war narratives in film are also usually simplified and the protagonists are presented in a way that the public

\footnotetext{
${ }^{7}$ Russell J. A. Kilbourn, Cinema, Memory, Modernity: The Representation of Memory from the Art Film to Transnational Cinema, Routledge Advances in Film Studies 6 (New York: Routledge, 2010), 1.

${ }^{8}$ Astrid Erll and Ansgar Nünning, eds., Media and Cultural Memory : Cultural Memory Studies : An International and Interdisciplinary Handbook (Berlin: Walter de Gruyter, 2008), 5.

${ }^{9}$ А.И. Афанасьева and В.И. Меркушин, “Великая Отечественная Война в Исторической Памяти Россиян (In English: Great Patriotic War in the Historicla Memory of Russians)," Социологические Исследования, 2005, 11-22.

${ }^{10}$ Elazar Barkan, The Guilt of Nations: Restitution and Negotiating Historical Injustices, 1st ed. (New York: Norton, 2000), x.

${ }^{11}$ Anton Kaes, "History and Film: Public Memory in the Age of Electronic Dissemination," History and Memory 2, no. 1 (Fall 1990): 111-29., 111-14.
} 
could identify themselves with the heroes. ${ }^{12}$ Since film tends to influence people emotionally, the information that is transmitted is also better remembered. Furthermore, film gives the impression that viewers are experiencing the events themselves, which means that they take it closer to heart and see it as part of their own lives.

Gary R. Edgerton and Peter C. Rollins explain that television history uses the past "as a kind of communal, mythic response to current controversies, issues, and challenges" and “facilitates a society's ongoing negotiation with its usable past by portraying those parts of the collective memory that are most relevant at any given time." 13 The fact that the Second World War receives more and more attention from television, in forms of fiction, documentaries or news stories, proves that the topic is relevant in contemporary Russia. It shows that media channels, filmmakers and the general public are preoccupied with the meaning of war. Furthermore, we see that authorities are not only encouraging the transmission of the Second World War memory, but they are also dictating the way the event should be interpreted. For example, the Presidential Commission held a roundtable on the November 19, 2012 where the state decided to protect Russian historical memory, which among others includes the liberation of Europe from the fascists, by introducing legislation that punishes the rehabilitation of Nazism and stimulates the production and distribution of TV and radio programs that popularize history. ${ }^{14}$ This demonstrates that the interest in the Second World War is not only based on public demand, it is "usable past" for the state in order to promote a special form of patriotism, i.e. respect for their motherland. Stalingrad serves as one of the

\footnotetext{
${ }^{12}$ Gary R. Edgerton and Peter C. Rollins, eds., Television Histories: Shaping Collective Memory in the Media Age (Lexington: University Press of Kentucky, 2001)., 1-8.

${ }^{13}$ Ibid.

14 “О Противодействии Попыткам Фальсификации Истории Народов в Ущерб Интересам России (In English: Countering the Attempts to Falsify Nation's History in Order to Harm Russian Interests)," accessed November 19, 2012, http://council.gov.ru/activity/activities/roundtables/30331.
} 
examples of the popularization of history, since the production was partly supported by the Ministry of Culture of the Russian Federation shortly after the roundtable. ${ }^{15}$

Film is also a creation, and it is thus important to see how cultural memory itself has influenced the production of a particular film. The director and writer belong to the community, they are similarly influenced by the cultural context that they live in. Subsequently one can see film both as a product of cultural memory and as an agent that carries memory further; film allows us to see not only what is remembered from the war, but also how it is remembered and by whom.

This thesis analyzes how the film Stalingrad promotes patriotism through the use of cultural memory. Stalingrad was directed by Fedor Bondarchuk, its screenplay written by Ilya Tilkin and Sergey Snezhkin based on Vassili Grossman's novel "Life and Fate." The film was released in September 2013 in Volgograd (the former Stalingrad). It is a feature film that portrays the Battle of Stalingrad in 3D format. Stalingrad became a blockbuster that was shown in the cinema as well as on TV. Therefore it is an excellent example of popularization of history that reached large audiences. As a cultural memory tool, this film transmits the contemporary perception of the Second World War that is considered as one of the grounding myths for Russian nation-building. The aim of this thesis is to make an interdisciplinary analysis of the film, by incorporating both historical developments of the Second World War film, as well as the messages the film as the work of art communicates and put it into the contemporary socio-political context.

The first chapter of the thesis explains the concepts of cultural memory, and its connection with national identity, politics of memory and patriotism. The different levels of

\footnotetext{
15 “Владимир Мединский Озвучил Результаты Работы По Поддержке Отечественного Кинематографа (in English: Vladimir Medisnki Announced the Results of the Support for Domestic Cinema)," Министерство Культуры Российской Федерации, December 2, 2014, http://mkrf.ru/presstsentr/novosti/ministerstvo/vladimir-medinskiy-ozvuchil-rezultaty-raboty-po-podderzhke-otechestvennogokinem.
} 
interaction between film and memory will be analyzed, as well as the different techniques that film as an audio-visual medium employs in order to affect cultural memory. This discussion also provides the framework for subsequent analysis by explaining the methodology used.

The second chapter of the thesis gives an historical overview of cinema's role in the Soviet nation-building process, particularly in transmitting state's ideology and values. In addition, the development of Soviet Second World War films will be summarized to demonstrate the changes in the perception of the war over time. By showing how the war has been portrayed previously one can understand the cultural context of contemporary films. Since filmmakers and audience are influenced by the previous narratives and war film traditions, this will eventually affect the production as well as the reception of the 2013 film Stalingrad.

The third chapter of the thesis concentrates on the film's analysis from the perspective of cultural memory. This part distinguishes particular ways how the portrayal of the Battle of Stalingrad in the film influences the interpretation of the war and fosters patriotism. It is also important to see how the previous cultural context is incorporated into the film in order to communicate the meaning of the event. Since patriotism is reinforced by the use of symbols and narratives, the chapter distinguishes narratives used in the film and analyzes how they coincide with the developments in the contemporary Russian society. This research is concentrated on studying the ways cultural memory is used for fostering patriotism; the reception of the film, as well as the techniques used for attracting wider audience will be subsequently analyzed. 


\section{CHAPTER ONE: CULTURAL MEMORY AND FILM}

Memory, according to Dennet and Westbury, is "the ability to store useful information and to retrieve it in precisely those circumstances and that form which allow it to be useful." 16 Similarly, Jedlowski sees memory as "the human faculty of preserving certain traces of past experience and having access to these - at least in part - through recall."17 "Storing" or "preserving" memories means that they are not generally in use, they need triggers in order to appear, or as Maurice Halbwachs explains, they are unconscious and become conscious only when they are revived. ${ }^{18}$ On this basis, one can understand that people need particular events, rituals, or stories to recollect their memories and recall important past events. It does not mean, however, that the memories are static or remain the same over the course of time. Memory studies show that people do not remember accurately and that their memories change depending on the time and circumstances. ${ }^{19}$ As Pierre Nora states, memory "remains in permanent evolution, open to the dialectic of remembering and forgetting, unconscious of its successive deformations, vulnerable to manipulation and appropriation, susceptible to being long dormant and periodically revived." ${ }^{20}$ Memory is complicated, it can transform spontaneously, or it can be changed through institutions, however, it is always connected with a particular time.

The conceptualizer of collective memory, Halbwachs suggests that people reconstruct their memories due to the social pressure: "[S]ociety from time to time obligates people not just reproduce in thought previous events of their lives, but also to touch them up, to shorten

\footnotetext{
${ }^{16}$ Daniel C. Dennett and Chris Westbury, "Mining The Past To Construct The Future: Memory and Belief as Forms of Knowledge," in Memory, Brain, and Belief (Harvard University Print, 2000), 11-32, 13.

${ }^{17}$ Paolo Jedlowski, "Memory and Sociology: Themes and Issues," Time \& Society 10, no. 1 (March 1, 2001): 29-44.

${ }^{18}$ Maurice Halbwachs, On Collective Memory (Chicago: University of Chicago Press, 1992).

${ }^{19}$ Jedlowski, "Memory and Sociology: Themes and Issues," 30-32.

${ }^{20}$ Pierre Nora, "Between Memory and History: Les Lieux de Mémoire," Representations, no. 26 (April 1, 1989): 7-24, 8 .
} 
them, or to complete them so that, however convinced we are that our memories are exact, we give them a prestige that in reality they did not possess." ${ }^{21}$ Collective memory acknowledges that individual memory is strongly linked to social contexts; however, it draws a distinctive line between social and cultural frameworks and does not regard the latter in the concept of memory, but rather sees it as tradition. ${ }^{22}$ Since film connects fictional texts with visual images, its role in the contemporary Russian memory cannot be wholly analyzed from the perspective of collective memory.

\section{Cultural Memory}

Cultural memory theorists Jan and Aleida Assmann developed Halbwachs' concept of collective memory further and state that there is a need to distinguish two different terms on the basis of temporal structure: "communicative memory" and "cultural memory." 23 Communicative memory is a synchronic memory space that is transmitted from one generation to another, while cultural memory is diachronic and reaches far back in time. ${ }^{24}$ Communicative memory is based on socialization and transmits autobiographical accounts of recent events, reflects values, attitudes, beliefs of generations, and thus helps people to "live in groups and communities." ${ }^{25}$ Although cultural memory functions also as a bonding memory, its content is different due to its temporal range. According to Jan Assmann, cultural memory carries further the "mythical history" of groups with the help of objectified culture

\footnotetext{
${ }^{21}$ Halbwachs, On Collective Memory, 51-53; Jan Assmann, Religion and Cultural Memory: Ten Studies (Stanford, CA: Stanford University Press, 2006), 8.

${ }^{22}$ Halbwachs, On Collective Memory, 51-53; Assmann, Religion and Cultural Memory, 8.

${ }^{23}$ Erll and Nünning, Media and Cultural Memory, 109-17.

${ }^{24}$ Assmann, Religion and Cultural Memory, 8.

${ }^{25}$ Christian Emden and David R. Midgley, Cultural Memory and Historical Consciousness in the GermanSpeaking World Since 1500: Papers from the Conference “The Fragile Tradition”, Cambridge 2002 (Peter Lang, 2004), 22-24; Erll and Nünning, Media and Cultural Memory, 109.
} 
such as texts, images and rituals. Therefore, it involves not only social but also cultural context. $^{26}$

The Second World War is an event that still fits into the temporal range of communicative memory: there are eyewitnesses alive and the information is passed further with vernacular language. However, as soon as communicative memory takes the form of a cultural product, for example literature or film, it uses formalized language, symbols, emplotted narratives, and therefore is considered as cultural memory. ${ }^{27}$ Here, one can see the Second World War as a "fixed point," a "figure" of cultural memory: it is a meaningful event that is communicated to the audience through different cultural formations. Since the war has become a "myth," a formative text that constitutes identity and promotes self-definition, the war receives also a different temporality, and it no longer is connected with real time. ${ }^{28}$

All cultures have developed forms of communication and ways to preserve information that is necessary for formation and continuation of cultural memory. ${ }^{29} \mathrm{~A}$ precondition for cultural heritage is thus the existence of "objectification or crystallization of communicated meaning and collectively shared knowledge." 30 This information is transmitted and stored with the help of text; however, the meaning of text in cultural memory, as already constituted, is not only found in written or oral accounts but also images, sounds and customs. $^{31}$

Cultural memory is similarly to individual memory divided into two categories based on their functions: "active memory" and "archival memory." The first implies the texts that are currently in use, the latter on the other hand resembles individual involuntary memory that

\footnotetext{
${ }^{26}$ Erll and Nünning, Media and Cultural Memory, 5, 109-17.

${ }^{27}$ Assmann, "Collective Memory and Cultural Identity," 128.

${ }^{28}$ Ibid., 129; Assmann, Religion and Cultural Memory, 38.

${ }^{29}$ Emden and Midgley, Cultural Memory and Historical Consciousness, 31.

${ }^{30}$ Assmann, "Collective Memory and Cultural Identity," 130.

${ }^{31}$ Assmann, Religion and Cultural Memory, 7-8; Emden and Midgley, Cultural Memory and Historical Consciousness, 31 .
} 
becomes active only through recall. ${ }^{32}$ According to Jan Assmann, activating cultural memory means that people "turn to the archive of cultural traditions, the arsenal of symbolic forms, the imaginary of myths and images, of the great stories, sagas and legends, scenes and constellations." ${ }^{33}$ The "figures of memory" are activated, however, based on present needs, their meaning interpreted through contemporary perspective. Since every era relates differently to the information - by criticizing, appropriating, preserving or transforming - one event can be seen very differently depending on the particular context. ${ }^{34}$ For instance, the next chapter about the development of the Second World War memory in Soviet and Russian cinema illustrates how differently the war was portrayed in different eras. The main questions: who should take the credit for the victory, as well how it was fought and by whom, are constantly under observation. The importance of the event for the nation, however, has almost never been questioned, the evidence for which are numerous films, literary works, and monuments devoted to this topic.

These cultural memory tools, on the other hand, cultivate memory of the Second World War, which means that the remembrance of the event is organized. Cultural memory "depends on specialized practices," on "canonized texts" that are institutionally communicated to groups. ${ }^{35}$ Erecting monuments or organizing celebrations are practices similar to producing films: they all work as "memory aids" and help not to forget the significant events. ${ }^{36}$ In addition, constant attention on one event and institutional selection of its elements and the ways it is portrayed, not only stresses the relevancy, but makes it "sacred" and thus turns it into canon. ${ }^{37}$ The Second World War films were canonized already in the Soviet period and contemporary Russian cinema uses these canons in fostering the

\footnotetext{
${ }^{32}$ Emden and Midgley, Cultural Memory and Historical Consciousness, 31.

${ }^{33}$ Assmann, Religion and Cultural Memory, 7-8.

34 Ibid., 130-32.

${ }^{35}$ Assmann, "Collective Memory and Cultural Identity," 131.

${ }^{36}$ Assmann, Religion and Cultural Memory, 8-9.

${ }^{37}$ Ibid., 19.
} 
importance of the event to the nation. ${ }^{38}$ Therefore, it is necessary to understand what the purpose of the cultivation is.

The fact that the Second World War is significant or made significant through canonization means that it carries values significant for the group. Jan Assmann states that cultural memory supplies a group with knowledge and symbols that are necessary for its “normative self-image” as well as for its system of values. ${ }^{39}$ Heiko Pääbo's comparative study of Russian, Estonian, Ukrainian and Georgian master narratives reveals that Russian selfimage is predominantly positive and stresses the glorifying elements. According to Pääbo, the glorification is mainly connected with military, political and cultural achievements. The greatest heroic accomplishment is considered to be the victory in the Second World War that constructs the image of a "defender of peace and just cause." ${ }^{40}$ Russians also consider their culture to be very distinctive and thus believe they descend from a unique civilization that was established already over thousand years ago by Kievan Rus. ${ }^{41}$ Acknowledging that master narratives are constructed with the help of cultural memory, the heroic self-image and the representation of a distinct Russian civilization are thus the products of cultural tools that bind a group, by educating, civilizing and offering "rules of conduct." 42

Self-image, on the other hand, is connected with making clear distinctions between "us" and "them." Jan Assmann points out that the main characteristic of cultural memory is that it "preserves the store of knowledge from which a group derives an awareness of its unity

\footnotetext{
${ }^{38}$ Александра Талавер, “Память о Великой Отечественной Войне в Постсоветском Кинематографе (In English: Memory of the Great Patriotic War in Post-Soviet Cinema)," Философия и Исследования Культуры, Этапы Осмысления Прошлого (от 1990-х к 2000-м, Т16 (2013): 28; Denise J. Youngblood, Russian War Films: On the Cinema Front, 1914-2005 (Lawrence: University Press of Kansas, 2007), 231.

${ }^{39}$ Assmann, "Collective Memory and Cultural Identity," 131-32.

${ }^{40}$ Heiko Pääbo, Potential of Collective Memory Based International Identity Conflicts in Post-Imperial Space: Comparison of Russian Master Narrative with Estonian, Ukrainian and Georgian Master Narratives (PhD diss., Tartu University Press, 2011), 257-60.

${ }^{41}$ Ibid., 260.

${ }^{42}$ Assmann, "Collective Memory and Cultural Identity," 131-32.
} 
and peculiarity." ${ }^{\prime 3}$ Thus, cultural tools such as stories, celebrations and symbols help to define a group's identity by determining who belongs to the group and who does not. If cultural memory accumulates and mediates knowledge of ancestors to groups, unites communities on the basis of "mythical histories," and presents historical events from current perception, then it serves also as a precondition for nation-building.

\section{National Identity, Politics of Memory and Patriotism in Cultural Memory}

The ethno-symbolist approach in nationalism studies perceives a very close connection between cultural memory and national identity. According to Anthony D. Smith, among other phenomena, national identity incorporates "historical myths and memories," i.e. cultural memory. ${ }^{44}$ One can understand that people need memories in order to know who they are, both on the individual and on the group level. This explains the overall preoccupation with the past among nations, which try to find legitimization for their own state's existence by looking back at history. However, as Aleida Assmann notes, nations do not have a memory, they create their memory through "memorial signs." ${ }^{45}$ These signs, whether monuments, symbols or texts, carry connective semantics and help to construct national identity. ${ }^{46}$

Religion is very significant for the formation of national identity, since it unites people through different rituals, customs and ceremonies that are continuously practiced, thus creating a symbolic foundation for the public culture. ${ }^{47}$ Furthermore, Northrop Frye sees Christian religion as a "great code," meaning that culture is very closely related to the

\footnotetext{
${ }^{43}$ Ibid., 130.

${ }^{44}$ Anthony D. Smith, National Identity (Reno: University of Nevada Press, 1991), 14.

${ }^{45}$ Emden and Midgley, Cultural Memory and Historical Consciousness, 26.

${ }^{46}$ Ibid.; Assmann, Religion and Cultural Memory, 11.

${ }^{47}$ Assmann, Religion and Cultural Memory, 11; Anthony D. Smith, Ethno-Symbolism and Nationalism: A Cultural Approach (New York, Oxon: Routledge, 2009), 51.
} 
religion: works of art refer to biblical themes and in order to interpret them, one has to know Christian myths. Frye's concept of myth coincides with Asmmann's: it is a "sacred" story that transfers important lessons, values and ideology. ${ }^{48}$ Thus, religion serves as a medium as well as an archive of information about a nation's (culture's) past; it connects generations across centuries or millennia and constitutes the continuation of a community. ${ }^{49}$ In addition, Smith asserts that religion is the most effective way to create national identity, because it allows people to believe they are chosen by God. He calls it the "election myth" and considers this also crucial for ethnic survival. Among others, he speaks about particular "chosen peoples," for instance Russians have seen their state as "the sole bastion of Orthodoxy in an heretical world, the third Rome" already from 1453, when the Byzantine empire was extinguished. The Tsar became a "“father' to his chosen people in holy 'mother Russia." 50 The "gendered political emblems of motherland and fatherland" in turn, together with distinctive flags, were another step in nation-building, because they distinguished one group from another. ${ }^{51}$

Cultural memory not only offers the content for national identity, but also serves as a medium. In order to assure homogeneity, national identity needs to be communicated to all the members of the group and, according to Smith, this is done through "mass culture." In his opinion, education and mass media are effective tools in uniting people by transmitting the narratives that constitute a nation. ${ }^{52}$ Since mass media itself "refers to forms and texts that work in unison to generate specific dominant or popular representations of events, people, and places," it is important to acknowledge that films as mass media are in fact used in the nation-

\footnotetext{
${ }^{48}$ Northrop Frye, The Great Code: The Bible and Literature (Toronto: University of Toronto Press, 2006), 7-15, 49-65; Northrop Frye, Northrop Frye on Religion: Excluding The Great Code and Words with Power (Toronto: University of Toronto Press, 2000), 4.

${ }^{49}$ Assmann, Religion and Cultural Memory, 11.

${ }^{50}$ Anthony D. Smith, “Chosen Peoples: Why Ethnic Groups Survive," Ethnic \& Racial Studies 15, no. 3 (July 1992): 440-45.

${ }^{51}$ Smith, Ethno-Symbolism and Nationalism, 51.

${ }^{52}$ Smith, National Identity, 11, 14., Susannah Radstone and Bill Schwatz, eds., Memory: Histories, Theories, Debates (New York: Fordham University Press, 2010).
} 
building process by presenting historical events or myths that are important to a particular nation, thus creating a unifying identity beyond village or town. ${ }^{53}$

Aleida Assmann asserts that cultural memory "translates and transcends the other memory formats," including the political. ${ }^{54}$ Political construction of memory therefore, like national identity, relies on cultural practices, myths and symbols that are provided by cultural memory. ${ }^{55}$ Both Jan and Aleida Assmann state that political memory strives to unite people on the basis of remembering significant events or myths. ${ }^{56}$ The characteristics of political memory are thus emotionally charged narratives that supply people with stimulating messages and continuous reactivation of visual signs and performative action. However, only these parts of the past are used that foster a positive self-image and support future goals. ${ }^{57}$ Similarly, one can observe that Stalingrad transmits a heroic event with a simple plot; it accentuates the greatest battle of the Second World War that is considered to have changed the course of the war. The reason why the Battle of Stalingrad is necessary to communicate to contemporary audience is that it portrays the Russian state as a great power, and the Russian nation as invincible and brave.

According to Jan Assmann, the "participation structure of cultural memory has an inherent tendency to elitism; it is never strictly egalitarian." ${ }^{58}$ Institutions control or channel their interpretation of the nation's past to those who inhabit it. Erik Meyer frames the concept of memory politics with two practices: "policy for the past" (Geschichtspolitik) and "politics of history" (Vergangenheitspolitik). The latter can be used in states where there is transition from a totalitarian to a democratic regime, and provides an account of how societies come to

\footnotetext{
${ }^{53}$ Marita Sturken and Lisa Cartwright, Practices of Looking: An Introduction to Visual Culture (Oxford ; New York: Oxford University Press, 2001), 151-53.

${ }^{54}$ Emden and Midgley, Cultural Memory and Historical Consciousness, 36.

${ }^{55}$ Ibid., 35.

${ }^{56}$ Assmann, Religion and Cultural Memory, 7; Emden and Midgley, Cultural Memory and Historical Consciousness, 35.

${ }^{57}$ Emden and Midgley, Cultural Memory and Historical Consciousness, 26-28.

${ }^{58}$ Erll and Nünning, Media and Cultural Memory, 116.
} 
terms with the past. Geschichtspolitik, on the other hand, deals with the history of a community that has controversial understandings of past events. Politics of history is accordingly when actors gain political power through transmitting their interpretation of history and influence public debates to reshape the narrative. Moreover, public political communication is mainly performed via mass media. Meyer explains that in this case there is a competition for "hegemony" over the narratives and interpretations not only among politicians, but also among academics and journalists. ${ }^{59}$ Since competing discourses presented to the public influence collective memory and national identity, the politics of history is not solely the dominion of state authorities. If films are in fact able to change or modify what people think they know about the past, one can easily add filmmakers or the sponsors of films to this category.

Some scholars are reluctant to label everything as an intentional transmission from above. One should not see politics of memory only as a "manipulation" by the elites, instead it is necessary to see that memory operates also from below. Winter and Sivan highlight that “much 'memory work' goes on spontaneously within civil society, especially after salient or dramatic events. ${ }^{90}$ Looking at film as a mechanism for communicating past narratives, it is important to be aware that its creators are also part of the nation; they are influenced by the same cultural memory that they share with the rest of the group. It means that they produce films or incorporate events that are important for them as representatives of their shared culture. They can also produce films that are interesting for the audience, thus they try to meet public demands by incorporating present concerns of their society over history and memory that stimulate or engage public attention.

\footnotetext{
${ }^{59}$ Ibid. 174-76.

${ }^{60}$ Jay Winter and Emmanuel Sivan, War and Remembrance in the Twentieth Century (Cambridge, New York, Melbourne: Cambridge University Press, 2000), 17.
} 
National identity, or belonging to one community, and politics of memory, as an organized way to foster particular remembering, are in turn preconditions for patriotism, which is described as loyalty to a nation or a state. According to Herbert C. Kelman, patriotism does not have to be connected to the nation-state, because it is more general and older than the modern concept of nationalism. In addition, one can be a patriot of an entity that does not possess a state. ${ }^{61}$ Still, the concepts of nationalism and patriotism are sometimes used as synonyms, especially regarding modern nation-states. Igor Primoratz explains that both patriotism and nationalism mean love for and identification with one particular entity all in all they are "the same type of a set of beliefs and attitudes." 62 These concepts overlap in the cases when a country is ethnically homogeneous, but may be reversed in a multiethnic state. ${ }^{63}$ Nationalism has also a negative connotation, it is seen not only as belonging to a group and being proud of its achievements and merits, but can also discriminate other nations, claim superiority of one's nation or country. ${ }^{64}$

Although, in Russia, patriotism has nationalist character, one cannot easily apply the term nationalism. First, Russia is a multiethnic state, by promoting the achievements of one particular nation and culture, the goal of the authorities is not to make so much distinctions between one or another nation, but rather assimilate other ethnic groups to a larger community and offer them an alternative identity and past achievements based on one political entity. Second, concepts must be used in a particular context, since nationalism is commonly associated with Nazism, Russians themselves avoid using it, and prefer a more neutral one, i.e. patriotism.

\footnotetext{
${ }^{61}$ Herbert C. Kelman, "Nationalism, Patriotism, and National Identity: Social-Psychological Dimensions," in $D$. Bar-Tal \& E. Staub (Eds.), Patriotism in the Life of Individuals and Nations (Chicago: Nelson-Hall, 1997), 16667.

62 Igor Primoratz and Aleksandar Pavkovic, Patriotism : Philosophical and Political Perspectives (Abingdon, Oxon, GBR: Ashgate Publishing Group, 2008), 18.

${ }^{63}$ Ibid.

${ }^{64}$ Ibid., 129-130; Erika Harris, Nationalism: Theories and Cases (Edinburgh, GBR: Edinburgh University Press, 2009), 4-7.
} 
However, states are dependent on patriotism for legitimizing state existence, for ensuring popular support and loyalty. ${ }^{65}$ Therefore, it is necessary to understand that state leaders do emphasize patriotic feelings for establishing a state, or for assuring its continuity. As Carretero asserts, patriotism deals with values that are important for the present and the future: it is a social construction that is mediated with the help of culture. ${ }^{66}$ Patriotism, like national identity, relies partly on objectified culture in the form of symbols, ceremonies, and rituals that are communicated to larger groups. Thus, patriotism uses cultural memory for both content and communication.

Looking at contemporary Russian war films, Stephen M. Norris asserts that they are tools for fostering Russian patriotism, since they employ sentimentality, emotionality and nationalistic enthusiasm for portraying war. It is also important to notice that one of the patriotic films Norris refers to is Company 9 (9 poma, 2005) about the Afghan War, directed by Fyodor Bondarchuk, who is also the director of Stalingrad. Furthermore, contemporary Russian cinema critic Arkhangelskii sees that Bondarchuk in his films follows authorities' instructions by fostering patriotism. ${ }^{67}$

All the above mentioned concepts have one thing in common: they are all strongly linked with mass media, since they function effectively only when communicated to larger audiences. Mass media is seen as a crucial part of the emergence of nations in Europe. Benedict Anderson asserts that novels and newspapers provided "technical means" for transmitting the sense of the "imagined community" to a larger population. ${ }^{68}$ Written media was available to people who were able to read and therefore did not have such effects on the

\footnotetext{
${ }^{65}$ Kelman, "Nationalism, Patriotism, and National Identity: Social-Psychological Dimensions," 166.

${ }^{66}$ Mario Carretero, Constructing Patriotism: Teaching History and Memories in Global Worlds (IAP, 2011), $119-22$.

${ }^{67}$ Андрей Архангельский, “Приказано Выжать (In English: Ordered to Squeeze It Out),” Искусство Кино, November 2013, http://kinoart.ru/ru/archive/2013/11/prikazano-vyzhat.

${ }^{68}$ Benedict Anderson, Imagined Communities Reflections on the Origin and Spread of Nationalism (London: Verso, 1983), 25.
} 
illiterate population. Sturken and Cartwright rightly point out that audio-visual media had in fact a large effect on society in the beginning of the twentieth century. With the emergence of audio-visual media, such as film and radio, illiterate masses were included within so-called "imagined communities" since they too had access to the narratives "beyond the word of mouth." They also point out, however, that opinions among scholars differ as to whether the access of non-literate population to the information flow supported democratization or led to more state control (or the control of the producers) over society. ${ }^{69}$ That question is, of course, dependent on the particular political culture, but one can assume that totalitarian states are interested in controlling the population and use mass media, including films, to support the existing regime. For instance, Richard Taylor in his study of film propaganda in Nazi Germany and Soviet Russia, shows that authorities were well aware of the influences of film on the people and used it as efficient tool for promoting state ideology as well as for the nation-building process. $^{70}$

\section{The Influences of Film on Cultural Memory}

One of the research questions of this thesis is focused on the ways that the Stalingrad film influences the interpretation of the war as well as the reception of information about the event. This section further explains this question from the perspectives of cultural memory theorists and psychology.

Film as a mass medium is a powerful tool to shape society; it brings together a population, transfers notions of belonging among large populations and creates a common cultural memory. Many researchers, however, have also pointed out that film offers a very

\footnotetext{
${ }^{69}$ Sturken and Cartwright, Practices of Looking, 151-53.

${ }^{70}$ Richard Taylor, Film Propaganda: Soviet Russia and Nazi Germany (London, New York: I.B.Tauris, 1998).
} 
efficient way of learning about historical events. There is a common understanding that films are more influential in transmitting knowledge about the past than books or schools, since they are more popular, they are entertaining, interesting, simple, and close to reality. ${ }^{71}$ Youngblood adds that films may not be the most efficient method in channeling historical "facts," but they can involve people emotionally in stories that help in remembering narratives. ${ }^{72}$ Jan Assmann asserts that "only emotionally cathected forms of communication bring structure, perspective, relevance, definition, and horizon into memory." 73 People bond emotionally with fictional events portrayed in films because of the narratives and characters. Already in 1934 Hadley Cantril acknowledged that children and adults remember the material communicated by film because of their emotional attachment to the movie's plot. ${ }^{74}$ Similarly, LaBar and Cabeza's years of research proved that the events arousing emotions are more likely to be remembered than neutrally-charged events and that "[E]motion has powerful influences on learning and memory." 75 Van Damme and Smets add that emotions do not only help to remember better and more vividly, but can also create false memories. ${ }^{76}$ This also explains why memory is able to change depending on circumstances.

Mazierska asserts that the feeling of reality in films makes people believe that the things they viewed actually took place. ${ }^{77}$ Edgerton and Rollins add that television histories allow people to experience the events themselves and become part of them. They also point

\footnotetext{
${ }^{71}$ Sturken and Cartwright, Practices of Looking, 151-53; Kaes, "History and Film: Public Memory in the Age of Electronic Dissemination," 111-14; Edgerton and Rollins, Television Histories, 20; Ewa Mazierska, European Cinema and Intertextuality: History, Memory and Politics (Basingstoke, Hampshire [UK]; New York: Palgrave Macmillan, 2011), 11-14; Robert A. Rosenstone, "History in Images/History in Words: Reflections on the Possibility of Really Putting History onto Film," The American Historical Review 93, no. 5 (December 1, 1988): 1173-85; Hayden White, "Historiography and Historiophoty," The American Historical Review 93, no. 5 (December 1, 1988): 1196

72 Youngblood, Russian War Films, 3.

${ }^{73}$ Assmann, Religion and Cultural Memory, 3.

${ }^{74}$ Hadley Cantril, "Review of 'Motion Pictures and Youth: A Summary' and 'Getting Ideas from the Movies,"' The Journal of Abnormal and Social Psychology 29, no. 2 (July 1934): 238-39.

${ }^{75}$ Kevin S. La Bar and Roberto Cabeza, "Cognitive Neuroscience of Emotional Memory," Nature Reviews Neuroscience 7, no. 1 (January 2006): 54-64.

${ }^{76}$ Ilse Van Damme and Karolien Smets, "The Power of Emotion versus the Power of Suggestion: Memory for Emotional Events in the Misinformation Paradigm," Emotion 14, no. 2 (April 2014): 310-20.

${ }^{77}$ Mazierska, European Cinema and Intertextuality, 12.
} 
out that people relate to the characters on the screen and try to understand how the heroes must feel. ${ }^{78}$ Besides acquiring information from the films because the audio-visual components and the plot are engaging, the effect of "seeing it with your own eyes" and "living through" the events together with the heroes on the screen affects cultural memory. ${ }^{79}$ Based on that, the use of 3D technology in portraying the Second World War has the ambition to influence the reception of a historical event and therefore the memory of the war even more than a 2D film. There is new empirical research on the comparison of 3D and $2 \mathrm{D}$ film reception, revealing that viewers reported the $3 \mathrm{D}$ film as more realistic and engaging. ${ }^{80}$ The 3D technology has also proven to be successful for teaching different subjects in schools: it increases the ability to learn and improves exam results. ${ }^{81}$ All in all, adding the dimension of space to a film that already has a tendency to influence people emotionally increases the reception of the historical event and therefore allows the audience to feel that it is a part of the story.

In addition to $3 \mathrm{D}$ technology, music is also playing a great role in the emotional reception of film. According to Annabel J. Cohen, "music sets the mood of the film" and "bridges the gap between the screen and the audience." She also states that music adds an "emotional dimension" and allows an audience to engage in a film. ${ }^{82}$ Marilyn G. Boltz explains that many psychological studies prove that music affects the "perception,

\footnotetext{
${ }^{78}$ Edgerton and Rollins, Television Histories, 1-8.

${ }^{79}$ Mazierska, European Cinema and Intertextuality, 5; Kaes, "History and Film: Public Memory in the Age of Electronic Dissemination," 111-14; Edgerton and Rollins, Television Histories, 1-4; Tobias Ebbrecht, "History, Public Memory and Media Event," Media History 13, no. 2-3 (2007): 221-26.

${ }^{80}$ Brendan Rooney and Eilis Hennessy, "Actually in the Cinema: A Field Study Comparing Real 3D and 2D Movie Patrons' Attention, Emotion, and Film Satisfaction," Media Psychology 16, no. 4 (October 1, 2013): 44160.

${ }^{81}$ Khe Foon Hew and Wing Sum Cheung, "Use of Three-Dimensional (3-D) Immersive Virtual Worlds in K-12 and Higher Education Settings: A Review of the Research," British Journal of Educational Technology 41, no. 1 (January 1, 2010): 33-55.

${ }^{82}$ Annabel J. Cohen, "Film Music and the Unfolding Narrative," in Language, Music, and the Brain, vol. 10, Strüngmann Forum Reports (Cambridge, MA: MIT Press, 2013), 175.
} 
interpretation, and remembering of film information." ${ }^{83}$ Although the genre of Stalingrad could be named a thriller because of its portrayal of a battle, extensive shooting and fire, the music throughout the film is melodramatic. Hoeckner et al. provide an explanation for such a choice. Their study concentrated on finding out how different kinds of music influence the viewer's identification with certain characters. They came to the conclusion that melodramatic music provides "an interpretive context in which viewers would attribute to the character a distinct feeling of sadness and thereby increase their inclination to identify with the character." ${ }^{84}$ Hoeckner et al. found also that music helped to remember better the character's feelings as well as the associated clips. ${ }^{85}$

As an artistic creation, film may employ different techniques and genres, depending on the filmmakers' goals. This too affects the reception of mediated historical narratives and its overall effects on cultural memory. For example, films can connect history and memory through presenting stories as someone's memory. ${ }^{86}$ It can take the audience back in time, and it allows the public to experience recollection, especially when the film is not built as a linear story; for instance, it begins with the present and a key event forces the storyteller to remember particular events, in the same way as memory works in real life. It is also important to acknowledge that films which use first-person narrative usually present the events through the prism of the protagonist, which on the other hand resembles the stories people hear from their relatives or friends. If one adds the notion that films are influencing people unconsciously, these complicated and multilayered factors may play a role in creating and communicating cultural memory.

\footnotetext{
${ }^{83}$ Marilyn G. Boltz, "The Cognitive Processing of Film and Musical Soundtracks," Memory \& Cognition, 32 (7), 2004, 1194.

${ }^{84}$ Berthold Hoeckner et al., "Film Music Influences How Viewers Relate to Movie Characters," Psychology of Aesthetics, Creativity, and the Arts 5, no. 2 (May 2011): 146-53.

${ }^{85}$ Ibid.

${ }^{86}$ Mazierska, European Cinema and Intertextuality, 5.
} 
There are also differences in reception of genres. For example, Youngblood explains that art films are usually complicated and if it comes to memory, then they may not have such a strong influence as movies offering pure entertainment. Artistic films usually question the master narratives and this may come into conflict with the existing understanding that people have. Moreover, they are composed differently, which means that the audience has to work harder and pay much more attention to the non-linear narratives. One can add that the public is conscious when receiving information, and is able to acknowledge that art represents the creator's vision. Needless to say, film as an art form is also less popular than film as a form of entertainment. Moreover, feature films simplify stories that usually support the master narratives and reach wider audiences. ${ }^{87}$

It could be said that films as products and media of cultural memory do influence memory and identity in various ways: they can reinforce master narratives, offer alternative accounts thus questioning master narrative, add new features to the existing narratives, or help to forget topics by excluding them. The visual representation of the past together with an interesting story-line can help people to feel that the story could be part of their nation's history, but it should be supported by the master narrative or the other stories they have heard during their lifetime in order to have real effects.

\section{Film and Cultural Studies}

It is necessary to turn to cultural studies to understand film from the perspective of art. As already established earlier, cultural memory deals with objectified culture and sees texts as both the product of cultural memory as well as medium for communicating past events. Text,

\footnotetext{
${ }^{87}$ Youngblood, Russian War Films, 5; Mazierska, European Cinema and Intertextuality, 14.
} 
according to the cultural memory theorist, receives a wider meaning: it can be a painting, a ceremony, a book, or a film. Cultural studies, as its name presupposes, focuses on culture. Its key thinker, Stuart Hall, sees culture as societies' "practices, representations, languages and customs." ${ }^{88}$ Cultural studies research concentrates particularly on the "shared social meanings," i.e. how people understand the surrounding environments. ${ }^{89}$ Therefore, cultural studies are helpful in order to frame the present research by analyzing how the meaning is created. Since the present thesis concentrates also on how the portrayal of the war fosters patriotism, one has to see what this war means in the context of the film.

Semiotics has offered a very influential means for the analysis of cultural texts that is used both by mass media and art historians. The structuralist approach understands that culture should be seen in terms of its relationship to structure that lies outside of actors' intentions. ${ }^{90}$ This approach is influenced by Saussure's perception that language is a "system of signs that expresses the ideas," and that is governed by a "code," i.e. a set of usage rules. ${ }^{91}$ As examples, Saussure points to symbolic rituals and military signs that can similarly consider as a language. ${ }^{92}$ Language is used as a term that constitutes different ways of communication: pictures are also a means of communication. This understanding is also shared by Juri Lotman who considers art itself a "universal language," a work of art in turn is as a text that is created in the language prescribed by the particular form of art. ${ }^{93}$

Signs on the other hand are composed of signifiers and signifieds; however, Saussure asserts that the relationship between signifiers and signifieds is arbitrary, the meaning of signs

\footnotetext{
${ }^{88}$ Chris Barker, Cultural Studies: Theory and Practice, 2nd ed. (London, Thousand Oaks, New Delhi: SAGE, 2005), 7 .

${ }^{89}$ Ibid.

${ }^{90}$ Ibid., 16-17.

${ }^{91}$ Ferdinand De Saussure, Course in General Linguistics, trans. Wade Baskin (New York: The Philosophical Library, inc., 1959), 16.

92 Ibid.

${ }^{93}$ Juri Lotman, The Unpredictable Workings of Culture, 1st edition (Tallinn: Tallinn University Press, 2013), 127; Juri Lotman, Kunstilise teksti struktuur (In English: The Structure of the Artistic Text) (Tallinn: Tänapäev, 2006), 23.
} 
can change depending on the time and context. ${ }^{94}$ In addition to Saussure's concept of sign, Barthes proposes that there are two types of signs: denoted and connotative. In his opinion a denoted sign carries "literary" meaning, while a connotative sign is the product of associations with a denoted sign. ${ }^{95}$ Thus, according to Barthes, there is a "second system" of language that uses signs of the first system as signifiers, which he calls "metalanguage". ${ }^{96}$ In these terms a language of art could be seen as metalanguage, because it translates real life into art. ${ }^{97}$ In relation to the connotative sign, Barthes also explains the concept of "myth", which ideology. ${ }^{98}$ Here, one can see that myth is not just a story, but a sign that is a coded system of meanings.

Let us now analyze the structuralist approach in the context of film. Lotman asserts that there is a particular language of film that combines different elements: narrative is advanced further with pictures and sounds, by dividing scenes to footages, by changing speed of the footages, by zooming in, etc. As a work of art, it means that all of these elements carry particular meaning and thus become signs. It is similarly important to acknowledge that from the structuralist standpoint, the meaning of film lies in the "system of relations" of all of its elements; thus one can understand the artwork only when looking at it as a whole. ${ }^{99}$ Therefore, signs should be seen in relation with other signs, only then one can see what the meaning is. If film consists of narratives, pictures, sound, motion of footages, characters, etc., one has to understand what these elements mean not only separately but within the context of

\footnotetext{
${ }^{94}$ Saussure, Course in General Linguistics, 66-70.

${ }^{95}$ Roland Barthes, Elements of Semiology, trans. Annette Lavers and Colin Smith (New York: Hill and Wang, 1977), 89-94; Barker, Cultural Studies, 92.

${ }^{96}$ Barthes, Elements of Semiology, 92.

${ }^{97}$ Juri Lotman, Culture and Explosion, ed. Marina Grishakova, 1 edition (Berlin ; New York: Mouton de Gruyter, 2009), 150-151; Juri Lotman, Kultuurisemiootika (In English: Semiotics of Culture) (Tallinn: Olion, 1999), 49; Lotman, Kunstilise teksti struktuur, 19.

${ }^{98}$ Roland Barthes, "Myth Today," in Media and Cultural Studies: Keyworks, ed. Meenakshi Gigi Durham and Douglas M. Kellner (Hoboken: John Wiley \& Sons, 2009), 100-106.

${ }^{99}$ Lotman, Kultuurisemiootika (In English: Semiotics of Culture), 34; Юрий Лотман, Семиотика Кино и Проблемы Киноэстетики (In English: Semiotics of Cinema and Problems of Cinema Aesthetics) (Таллин: Ээсти Раамат, 1973), 3-41.
} 
the film. Therefore it is also necessary to understand what signs carry which associations, are they rooted in the culture (myths), or are created by the film.

However, the fact that connotations are rooted in the culture acknowledges that it is not possible to understand the meaning of an artwork without looking at the larger cultural context. This leads us to poststructuralism which considers meanings to be limited to one particular text. As Graham Bell notes, both literary and non-literary texts do not have "independent meaning," the meaning lies in the "network of textual relations." 100 "Text becomes intertext," which means that it is necessary to know all the related and referenced texts in order to understand the text. ${ }^{101}$ Intertextuality as a term was first marked by Julia Kristeva who saw it as "the insertion of history into a text and of this text into history." 102 If we add David Bordwell's notion that cinema is composed of all previous arts, one may conclude that film itself is by nature intertextual. ${ }^{103}$ Like all other texts, film is never finished; it will not end with screening, since film can be differently understood by different viewers in different times. Furthermore, the same person can interpret a film differently when watching it several times. The reception of film is always connected with the associations people have, which in turn depends on all the texts they have previously processed.

Art historian Erwin Panofsky, similar to poststucturalists, sees that art cannot be separated from previous texts or from the cultural context, but he adds a personalized vision to the interpretation and production. ${ }^{104}$ Hasenmueller sees that Panofsky's work can partly be considered semiotic, because he too asserts the dual character of signs (she argues that in Panofsky's vocabulary a sign is a motif, a connotative sign an image) and is concerned with

\footnotetext{
${ }^{100}$ Graham Allen, Intertextuality (New York, Abingdon: Routledge, 2011).

101 Ibid., 1-6; Lotman, Culture and Explosion, 69.

102 Allen, Intertextuality, 14; Adam Jaworski and Nikolas Coupland, The Discourse Reader, 2nd ed. (London, New York: Routledge, 1999), 184.

${ }^{103}$ David Bordwell, On the History of Film Style (Harvard University Press, 1997), 28-29.

${ }^{104}$ Erwin Panofsky, "Studies in Iconology," in Images: A Reader, ed. Sunil Manghani, Arthur Piper, and Jon Simons (London, Thousand Oaks, New Delhi: SAGE, 2006), 86.
} 
artwork's "deeper" meaning; however, his perception is that the system of signs is incomplete and secondary. ${ }^{105}$ Images and complexes of images (stories, allegories), according to Panofsky, carry conventional meanings, thus to interpret them "knowledge of literary sources" is applied. The analysis of this kind of interpretation is iconographic and understanding of an artwork's meaning is connected with person's identity and experience. ${ }^{106}$ Panofsky asserts the work of art is created by real people, who produced art within a concrete period of time in a particular place; therefore, an artist himself is influenced by the artistic environment and traditions. ${ }^{107}$

Panofsky says that film is subject to "principles of coexpressibility", one has to acknowledge that film is interpreted as a combination of sound and picture. Expression is, according to Panofsky, one part of the interpretation: film arouses emotions and gives impressions. However, these impressions are manipulated by the producers, because an audience sees the picture through the lens of a camera (for example magnification, camera angle). ${ }^{108}$ Thus, similar to the approaches of semiotics, Panofsky sees that all of the elements involved in the composition of film carry meanings. One of the tasks of the iconographic film analyst would be to recognize that there is a meaning for those elements. Another is to establish the meaning of images and this is done through applying conventional understandings and seeing "standardized appearance." 109 Panofsky acknowledges the role of environment and producers, which means that one could include the political sphere to the iconographical analysis - it does reflect on the outcome of artwork, since an artist is as influenced by the political culture as anyone else. However, Panofsky does not analyze the ways how artwork in turn influences audience.

\footnotetext{
${ }^{105}$ Christine Hasenmueller, "Panofsky, Iconography, and Semiotics," The Journal of Aesthetics and Art Criticism 36, no. 3 (April 1, 1978): 289-97.

106 Panofsky, "Studies in Iconology," 86-88.

${ }^{107}$ Erwin Panofsky, "Reflections on Historical Time," Critical Inquiry 30, no. 4 (Summer 2004): 697.

${ }^{108}$ Erwin Panofsky, "Style and Medium in the Motion Pictures," in Film Theory and Criticism, ed. Gerald Mast and Marshall Cohen (New York: Oxford University Press, 1985), 15-32.

109 Ibid., 25.
} 
Derived from the poststructuralist approach, this thesis acknowledges that every aspect of the film Stalingrad is meaningful and that it is important to see what message is created with the particular set of components. Narratology sees that the meaning lies in the structure of the text; both form and content are thus important. Narrative analysis deals with explaining how the different elements, such as plot and fable, narrator, addressee, characters, actions and settings, together contribute to the making of meaning. ${ }^{110}$ And since narrative is considered a valuable part of transmitting memory (it holds together collective remembering, follows particular developments in society and reflects old traditions and accommodates to new circumstances), the film Stalingrad needs to be analyzed from the perspective of narrative analysis to understand the meanings it holds in both the historical and the contemporary context. $^{111}$

Cultural theorist Stuart Hall, using the Marxist concept of cultural hegemony, analyzes the production and consumption of mass communication from the perspective of power relations. For Hall, a mass medium should be seen from the perspective of "encoding/decoding."112 Encoding means that the message created by the producers includes already their ideology, skills, institutional knowledge and assumptions about the consumers; this is all formed into a "meaningful discourse." Decoding on the other hand means that the message influences audience's perceptions and beliefs and thus has "cognitive, emotional, ideological or behavioral consequences." ${ }^{113}$ According to Hall, every culture has a specific "dominant cultural order" that constitutes the unambiguous and widely recognized connotative codes and "discursive domains." These in turn generate "dominant or preferred meanings" that are hierarchically organized and include institutional, political, and ideological

\footnotetext{
${ }^{110}$ Seymour B. Chatman, Story and Discourse: Narrative Structure in Fiction and Film (Ithaca and London: Cornell University Press, 1980), 15-29, 43-51.

${ }^{111}$ James V. Wertsch, Voices of Collective Remembering (New York: Cambridge University Press, 2002). 2-9.

${ }^{112}$ Stuart Hall, "Encoding/decoding," in Media and Cultural Studies: Keyworks, ed. Meenakshi Gigi Durham and Douglas M. Kellner (John Wiley \& Sons, 2009), 163-64.

${ }^{113}$ Ibid., 165.
} 
perceptions. ${ }^{114}$ Mass media operates on the encoding level with these codes and discourses, and can shape or reinforce the preferred meanings. Hall proposes three types of decoding: dominant-hegemonic code, means that audience understands the message similarly to the producers, the viewer shares the same views, interprets the connotative signs in similar way and agrees with the way it is presented. Negotiated code acknowledges the "legitimacy" of the preferred meanings, but sees that there can be exceptions. Oppositional code, on the other hand, denies the preferred meaning. ${ }^{115}$

Discourse analysis is closely connected with Hall's concept of cultural hegemony. Norman Fairclough, the critical discourse analysis' theorist, considers that texts have "causal effects," they can change society and identity by forming new knowledge, beliefs, values and attitudes. Fairclough argues that texts cause ideological effects that in turn "contribute to establishing, maintaining and changing social relations of power, domination and exploitation." 116 The film analysis contained in my study, therefore, acknowledges that Stalingrad has influence on the society; through representing a heroic event in a particular way it has the potential to reinforce patriotic feelings.

\section{Methodology}

This thesis aims to explain how the 2013 film Stalingrad reinforces patriotism in Russia. The analysis will be therefore concerned with the ways in which the film influences the perception of the war in cultural memory. It is similarly important to find out how the previous cultural context has influenced the portrayal of war, or what kind of discursive domains are present for

\footnotetext{
${ }^{114}$ Ibid., 169.

${ }^{115}$ Ibid.

${ }^{116}$ Norman Fairclough, Analysing Discourse: Textual Analysis for Social Research (London: Routledge, 2003), $3-9$.
} 
understanding the meaning that is communicated. Furthermore, the way in which portrayal of the war is connected with contemporary patriotism will be under observation, thus establishing its connection with cultural memory. Since the thesis will not only concentrate on the film as a work of art, but also as a cultural and social product that influences the society on different levels, my study will employ the method of critical discourse analysis in the discussion.

Critical discourse analysis (CDA) is a theoretical and methodological approach to study discourse in relation to social and cultural changes in society. There are different "movements" inside CDA that vary depending on the research object and methodology, however, they all share the notion that discursive practices are contributing to the organization of social relations and identities. ${ }^{117}$ All of these approaches also see "discourse" as an abstract term that "is an analytical category describing the vast array of meaning-making resources available to us"; the text under these conditions is seen as everything that can convey meaning - words, images, sounds and design. ${ }^{118}$ According to van Dijk, who covers such areas as mass communication, nationalism and identity within CDA, films can be similarly analyzed in the framework of CDA, because media is an influential tool in shaping the society. ${ }^{119}$

Since CDA focuses on power relations, one has to see the place film occupies in society's meaning-making process. Van Dijk explains that power is the control over a group's actions and perceptions. There are different types of power, but mass media as well as art have the ability to control society due to their authority, knowledge, or information. Usually there are dominant groups in society who control other groups, by prescribing the discourses

\footnotetext{
${ }^{117}$ Marianne W. Jørgensen and Louise J. Phillips, Discourse Analysis as Theory and Method (London, Thousand Oaks, New Delhi: SAGE Publications Ltd, 2002), 60.

118 Teun A. van Dijk, Discourse Studies: A Multidisciplinary Introduction, 2nd ed. (Los Angeles, London, New Delhi, Singapore, Washington DC: SAGE Publications Ltd, 2011), 357.

119 Teun A. van Dijk, "Critical Discourse Analysis," in The Handbook of Discourse Analysis, ed. Deborah Schiffrin, Deborah Tannen, and Heidi E. Hamilton (Malden, Oxford: Blackwell Publishers Inc., 2001), 361.
} 
that are in accordance with their needs, as well as with their ideology. ${ }^{120}$ Thus, we can look at film as a product created by smaller dominant group in order to influence society and communicate its ideology. Ideologies, as van Dijk defines it, are "general systems of basic ideas shared by the members of a social group, ideas that will influence their interpretation of social events and situation and control their discourse and other social practices as group members." ${ }^{121}$ Patriotism can be seen as ideology that influences citizens' perception of past and present events, and their attitude to their country's history. One has to also acknowledge however, that the Second World War occupies a very important position in Russian cultural memory: Russian master narratives include the war as one of the crucial events for the nation, and society has been receptive for decades to heroic portrayals of the war. The blockbuster film must therefore be seen also as a product that follows the conventional representation and conforms to "dominant cultural order" in order to be popular. Stuart Hall asserts that this can also be seen as domination over meaning. ${ }^{122}$ Therefore, analyzing film in the context of power, one has to see that the domination is both top-down as well as bottom-up process, but in any case, the hegemony over meaning and representation remains steadfast. In order to analyze Stalingrad as a medium of cultural memory, the CDA is an appropriate approach because it proposes to see text in the socio-political context. Furthermore, CDA engages other disciplines, which is important especially in the case of film, allowing us to integrate iconographic, narrative and intertextual analysis.

Let us now continue with explaining the research design of the analytical chapter. First, a short introduction to film will be provided. Since it is important for CDA to establish the actors of the communicative event, the production and reception will be briefly explained. The opinion polls and box office numbers will be included to illustrate the popularity of the

\footnotetext{
${ }^{120}$ Ibid., 354-55.

${ }^{121}$ Dijk, Discourse Studies: A Multidisciplinary Introduction, 380.

${ }^{122}$ Hall, "Encoding/decoding," 169.
} 
film. The circumstances of the release are integrated to show the framing of the film in the overall social context.

The second part of the analysis will analyze the film narrative in order to explain its structure. The relevant components for cultural memory will be elaborated, such as the plot, narrative voice, location, action and characters.

The third part will examine the choices made in incorporating music. Since music helps to remember the narratives by engaging people emotionally this part tries to outline the techniques used.

The fourth part will bring out the main narrative templates that are present in the film: "a holy war," "a war to save the motherland," "a war to save Russian civilization" and "a battle to the death." These narrative templates are partly motivated by Youngblood and Carleton's observations about war narratives in Russia. In addition to these four templates, the foreign influences on Russian war narratives will be analyzed. 


\section{CHAPTER TWO: HISTORICAL OVERVIEW OF CULTURAL MEMORY}

\section{AND FILM IN RUSSIA}

This chapter is divided into two sections. The first elaborates the role of film as the medium for creating national identity and how it has been used by the state in the Soviet Union and Russia. The second section is dedicated to the developments in the portrayal of war in Soviet era and Russian Federation.

\section{Film, Memory, Identity and Patriotism in the Soviet Union and Russia}

Mass media as a tool in the modern nation-building process has played an important role in Russia. David Brandenberger states that although national identity was promoted in Western Europe via education and media already in the nineteenth century, the same process occurred much later in Russia. According to Brandenberger, before the 1920s the vast population of Russia had identities that were regional or local and people didn't see themselves as part of a larger entity. In his opinion the nation-building process started together with the revolution and corresponded to the emergence of films. ${ }^{123}$ Sturken and Cartwright support this view and add that during the revolution filmmakers understood the power of visual media and used it in order to build "a new Soviet consciousness among illiterate Russian proletarians and peasants." ${ }^{124}$ Although Buganov does not agree with the abovementioned timeframes, and considers that national identity advanced together with the Great Reforms of the 1860 s, he

\footnotetext{
${ }^{123}$ David Brandenberger, National Bolshevism: Stalinist Mass Culture and the Formation of Modern Russian National Identity, 1931-1956. (Cambridge, Massachusetts, London: Harvard University Press, 2002), 2-33. ${ }^{124}$ Sturken and Cartwright, Practices of Looking, 153.
} 
still acknowledges that it was due to the spread of literacy. ${ }^{125}$ In either case, the access to visual media and to state propaganda increased the number of people who started to identify themselves as part of a larger community.

Similarly, the authorities were well aware of the effects of film and its role in distributing Marxist-Leninist ideology. ${ }^{126}$ Richard Taylor sees Soviet cinema as a "weapon" of state propaganda and states that both Lenin and Stalin acknowledged the power it had for "mass agitation." The reason why Soviet Russia used cinema as a main propaganda tool was because of its emotional rather than intellectual influences on the audience. In Taylor's opinion, it was more accessible for people and easily understandable. Cinema, being a "marvel" or "novelty" in the early Soviet times, also brought together people from different classes, social groups, and regions and was therefore used for unifying a nation and fostering patriotism. ${ }^{127}$ For example, Youngblood mentions that during the Civil War, footage from the front and "agit-films" with political messages about enemies and allies were not only brought to wider audiences by "agit trains," but they also had personnel who would explain the films. $^{128}$

Soviet mass media, especially films, were deeply tied to the agendas of political actors. The films were used as a tool to transfer the official narratives to people, which embraced, among other things, identity, memory and history. As Wertsch states, the Soviet Union tried to have very strict control over people's memory; alternative accounts were criticized and only the state's version of the past was allowed. Although state control had different forms throughout its existence, it was undoubtedly effective. Wertsch draws from the works of Heller and Nekrich in order to illustrate his point of view: history and memory

\footnotetext{
${ }^{125}$ Madhavan K. Palat, ed., Social Identities in Revolutionary Russia (Basingstoke: Palgrave Macmillan, 2001), 84.

${ }^{126}$ Taylor, Film Propaganda, 15-16; Brandenberger, National Bolshevism., 2-33.

${ }^{127}$ Taylor, Film Propaganda, 15-16.

${ }^{128}$ Youngblood, Russian War Films, 16.
} 
were "nationalized" to deprive people of their individual memory. ${ }^{129}$ Thus memory and history became similarly properties of the state, since the state controlled not only cultural memory, but also personal memories.

Different times needed different narratives and historical events in order to accommodate state interest and transfer them to people. With the building of a new state that was based on Marxism-Leninism, the authorities saw that it was necessary to unify people on the basis of the new ideology and to distance society from the old tsarist past. History was used to legitimize the state, and since history "proved" that the society was moving towards the socialist ideals, most of the narratives featured this notion. The complicated MarxistLeninist ideology, however, was difficult to grasp for the masses. ${ }^{130}$ Brandenberger points out that in the late 1920s and early 1930s, Stalin understood that Marxism-Leninism alone could not mobilize society and began to select different symbols and figures from the Russian past in order to legitimize the state and to foster the sense of motherland and patriotism among the people. In Brandenberger's view, this laid the ground for the contemporary Russian identity. ${ }^{131}$ This time also contributed to the development of particular patterns in Soviet master narratives that are, according to Wertsch, also employed by the current Russian authorities. $^{132}$

The overall stress on one version of the past or preoccupation with history and its "accuracy" that one can see nowadays started precisely at the same time. Wertsch explains that "Marxist-Leninist history" was labeled as the one and only true interpretation of the past. However, he also says that this official history did change over the course of time, particularly in its treatment of the achievements of certain people or their role in the events, and it was an

\footnotetext{
${ }^{129}$ Wertsch, Voices of Collective Remembering, 72-73.

${ }^{130}$ Ibid.,72-76; Brandenberger, National Bolshevism., 2-33.

${ }^{131}$ Brandenberger, National Bolshevism., 2-33.

${ }^{132}$ Wertsch, Voices of Collective Remembering, 75-76.
} 
individual's task was to keep track with this "truth" or otherwise he or she would become an enemy of the state. ${ }^{133}$ From the 1930 s the production of Soviet history was grounded squarely in the assumption that one immutable truth about the past existed. With each new version of history produced by the Soviet state, old ones had to be altered, discarded, and in many cases actively suppressed. The guiding principle might be termed "dogmatic, but temporary, truth" about the past. ${ }^{134}$

The essence of patriotism in the Soviet Union was similarly floatational, depending on circumstances. Dobrenko explains that after the end of the Second World War, new enemies were necessary to create in order to ensure the continuation of the state. From this point on the former Allies were seen as incarnation of evil. Patriotism, as the main tool in this process, was thus opposition towards all the external influences. The concept of patriotism itself was explained as love "for the soviet, socialist motherland," "for the social and governmental order" that is freed of exploitation. ${ }^{135}$ Dobrenko also adds that Soviet patriotism stressed the superiority of the country and saw Russians as pioneers in every cultural field of humankind. ${ }^{136}$ This in turn demonstrates that Russian patriotism has been closer to nationalism, even at times when multinationalism was officially promoted, since claiming superiority of Russians goes beyond the concept of patriotism. ${ }^{137}$

There are clear parallels between the current Russian state and the Soviet Union. One can understand that in contemporary Russia, as in the former Soviet Union, particular events are used as "foundation myths" of the state. As mentioned above, Stalin "hand-picked" figures or events from the tsarist era to show the continuity of the state. According to

\footnotetext{
133 Ibid., 77.

134 Ibid., 82.

${ }^{135}$ Евгения Добренко, Метафора Власти. Литература Сталинской Эпохи В Историческом Освещуении (In English: Metaphor of Power: Literature of the Stalin Era in Historical Context) (München: Verlag Otto Sagner, 1993), 382-83.

136 Ibid.

${ }^{137}$ Primoratz and Pavkovic, Patriotism : Philosophical and Political Perspectives, 129-134.
} 
Laruelle, Russian authorities similarly promote tsarist and Soviet past, by combining the greatest achievements of both entities while trying to diminish the contradictions. ${ }^{138}$ History thus serves the authorities in reasserting patriotic feelings. However, Laruelle also states that patriotism in Russia is actually "nationalist" in nature since it is constantly present in the political rhetoric and is used by all the political parties. Laruelle brings out the references by the politicians that can illustrate the main aspects of current patriotism: Russia as "Great Power," "statehood," "the preservation of the nation," "empire," "motherland," or "fatherland." Still, for different political parties patriotism means different things. It can be based on pre-Christian past, the pre-Soviet Russian empire, the Soviet era or Orthodoxy. Similarly to Russian nationalism, patriotism can have a "racist" character, because it accentuates on the supremacy of Russian ethnicity. ${ }^{139}$

To explain what practical functions patriotism plays for the current authorities, Laruelle emphasizes it use for political goals: to gain back respect for the army, to get more out of taxpayers, to diminish corruption, to contribute to the consumption of national products, etc. Patriotism, according to Laruelle, is also used to "modernize" and "Westernize" the country. In addition it stabilizes the society and promotes authorities' goals by reinforcing their conservative politics. ${ }^{140}$ All in all the use of patriotic rhetoric by the authorities serves to mobilize society for re-building a "Great Russia"141

One of the key events that is used by current authorities to foster patriotism is the Second World War, since it both legitimizes state's existence and reasserts its "Great Power"

\footnotetext{
${ }^{138}$ Marlene Laruelle, ed., Russian Nationalism and the National Reassertion of Russia (New York: Routledge, 2009), 3 .

${ }^{139}$ Ibid., 1-5, 25.

140 Ibid., 1.

141 Ibid., 25.
} 
image. ${ }^{142}$ Laruelle explains how Putin's administration thus "rehabilitated" Stalin in the history textbooks; furthermore, media is used to disseminate patriotic discourse about the war and Stalin's role, to strengthen Russian "national pride" and positive self-image. Among other media, cinema as well as internet is in Laruelle's opinion under the authorities' control. ${ }^{143}$

On this basis, let us now examine the concrete ways cinema and mass media are controlled. In year 2009 the Presidential Commission was created to protect the present official interpretation of the past or to counter its "falsification". ${ }^{144}$ The commission analyzed the information about falsification of historical facts and events that appeared to diminish Russian international prestige, and as a result developed a set of recommendations for the government. ${ }^{145}$ During the roundtable of November 19, 2012 the Council of the Federation came to a conclusion that preservation of Russia's historical heritage was one of the most important components of "spiritual-cultural" heritage and that its protection from falsification was necessary for strengthening Russian identity, the state, the unity of citizens, patriotism and national security. Here, Russia is described as a great multinational state, which enriched the world with its science and culture, and played a decisive role in saving the world from the fascist threat. In order to preserve Russia's historical heritage, the Council recommended that Government should, among other things, develop measures to stimulate the production and distribution of TV and radio programs as well as internet resources that would raise awareness and popularize this version of history. The Ministry of Education received a recommendation to increase the time dedicated to historical events in schools that are considered central to

\footnotetext{
${ }^{142}$ Elizabeth A Wood, "Performing Memory: Vladimir Putin and the Celebration of WWII in Russia," The Soviet and Post-Soviet Review, no. 38 (2011): 172-83; Laruelle, Russian Nationalism and the National Reassertion of Russia, 26.

${ }^{143}$ Laruelle, Russian Nationalism and the National Reassertion of Russia, 26.

144 “О Противодействии Попыткам Фальсификации Истории.”

145 “О Комиссии при Президенте Российской Федерации по Противодействию Попыткам Фальсификации Истории вУщерб Интересам России (In English: On the Presidential Commission for Countering the Attemts to Falsify History in Order to Harm Russian Interests)" (Указ Президента Российской Федерации от 15 мая 2009 г. N 549), accessed April 25, 2014, http://www.rg.ru/2009/05/20/komissia-dok.html.
} 
national consciousness, including the Second World War. ${ }^{146}$ Hence, the importance of the Second World War has been acknowledged by the authorities as a tool in the cultivation of a unifying identity. The war here represents the key event for Russian patriotism, since it stresses both victimization and heroism: it unites people on the basis of the common suffering and victory over the enemy. Pluralistic and alternative views of the event can therefore undermine the legitimacy of the USSR and its Russian successor state, since it questions the sacrifices made by the nation.

The fixation with "true" and "false" interpretations has lead to the place where large parts of public opinion and authorities are not willing to tolerate artistic freedom or freedom of expression. On April 4, 2014 the Russian Duma adopted legislation that punishes the "rehabilitation of Nazism" and the "distortion" of history that is connected with the Red Army's actions during the Second World War. According to the legislation, both individuals and mass media could be punished for distributing "false" information. Besides filmmakers and artists, this law will also affect historians who wish to study different versions and aspects of the war. Although the members of the Duma started to work on the legislation already in 2009, the work intensified and was finished due to the scandal around the TV channel "Rain" (“Дождь”). “TV Rain" asked its viewers if it was necessary to give up Leningrad to the Germans in order to save hundreds of thousands of people. ${ }^{147}$ The question was seen as an insult to the memory of the Second World War, and authorities wished to close down the station. Since there was no law that could forbid such opinion polling, the channel was not

\footnotetext{
146 “О Противодействии Попыткам Фальсификации Истории.”

147 “О Внесении Изменений в Уголовный Кодекс Российской Федерации и в Статью 151 УголовноПроцессуального Кодекса Российской Федерации (по Вопросу Установления Уголовной Ответственности за Посягательство на Историческую Память в Отношении Событий, Имевших Место в Период Второй Мировой Войны) (In English: On Amendments to the Criminal Code of the Russian Federation and Article 151 of the Criminal Procedure Code of the Russian Federation (on the Criminalization of Encroachment on Historical Memory in Relation to the Events That Took Place during the Second World War)" (Законопроект № 197582-5), accessed April 18, 2014, http://asozd2.duma.gov.ru/main.nsf/\%28SpravkaNew\%29?OpenAgent\&RN=197582-5\&02,.“Дума единогласно приняла закон против оправдания нацизма (In English: The Duma Unanimously Passed a Law Against Justification of Nazism)," BBC Russian, April 4, 2014, http://www.bbc.co.uk/russian/russia/2014/04/140404_nazism_duma_punishment.shtml.
} 
closed down; however, many sponsors withdrew their money and "TV Rain" had some severe financial problems for a while. ${ }^{148}$ One can thus understand that future filmmakers will not have the possibility to portray the Second World War in other than heroic terms, because one cannot show the Red Army or Stalin's flaws. The war portrayed in movies has to follow the line of "Russians are good" and "Germans are bad," thus limiting the discourse to simple confrontation. In this way the discourse of war will be synchronized in some sense, and the lack of contradictions will not confuse the audience. Constantly disseminating the same discourse would eventually unify the cultural memory.

One of the initiators of the abovementioned law and participants of the Presidential Commission was Vladimir Medinsky, appointed as the Minister of Culture in May 2012. Besides being a politician, he has also written a series of books about Soviet/Russian myths. In his writings he argues against the pluralist approaches to Russian history that began with glasnost. Medinsky considers films as an important medium for communicating past events. For example, in the book The War. The USSR's Myths. 1939-45 (2011) he dedicated one part to Russian and Western films about the Second World War. Among other foreign films, he pointed out the flaws in the representation of history from films like Saving Private Ryan, Inglorious Bastards and Pearl Harbor. Medinsky's biggest critique of these films seems to be the misrepresentation or absence of the Soviet Union's contribution to the war effort. Medinsky also either criticizes or praises Russian and Soviet films, and one can see that his goal is to "set the record straight." He further stresses the connection between his work and the state's views about Second World War cinema by adding three of Putin's favorite films under the section "Cinema for Putin." 149 This is a significant example how the authorities are

\footnotetext{
148 “Телеканал 'Дождь' под угрозой прекращения вещания (In English: Channel Rain is Under a Threat of Closing),” ВBC Russian, January 29, 2014, http://www.bbc.co.uk/russian/russia/2014/01/140129_tv_rain_conflict.shtml.

${ }_{149}$ Владимир Мединский, Война. Muфы CCCP. 1939-1945 (In English: War. Myths of USSR. 1939-1945), 2nd ed. (ОЛМА Медиа Групп, 2011).
} 
fixated with the "true" representation of past, but it also illustrates that they understand the significant role that cinema plays in mediating history.

The acts the government and the Duma have taken to limit "false" and to encourage "politically correct" representation illustrate the place that the Second World War occupies in achieving their political goals. The promotion and sponsorship of war movies have resulted in a growing number of films, both documentary and fictional. ${ }^{150}$ The war is an example of Russia as a "Great Power" and coincides with most of the above mentioned aspects of patriotism. The war stresses that people sacrificed themselves for their motherland, for their state, for their nation, while victory on the other hand reassures people of their strength and promotes a positive self-image. However, the present patriotism also stresses the tsarist past and Orthodox religion, and although they may not be compatible with the Soviet era achievement, we will illustrate how religion in particular is integrated to the war memory and thus becomes a bridge between two different pasts.

\section{Second World War Memory in Soviet and Russian films}

The portrayal of the Second World War on screen has gone through different developments that reflected the consciousness of the Soviet society and at the same time changed it. ${ }^{151}$ The transformations in remembering the war coincide with Aleida Assmann's notion of the generational shift. She argues that the change of generations is pre-eminent for "renewal and

\footnotetext{
150 Youngblood, Russian War Films, 219, 31.

151 Youngblood, Russian War Films., 1; Александр Шпагин, Великая Отечественная Войнав в Российском Кинематографе (In English: The Great Patriotic War in Russian Cinematography) (Телеканал “Дождь,” 2012), http://tvrain.ru/articles/aleksandr_shpagin_velikaya_otechestvennaya_voyna_v_rossiyskom_kinematografe$243935 /$
} 
reconstruction of social memory." ${ }^{152}$ Similarly, in the Soviet Union and in the Russian Federation, the Second World War was reviewed by each succeeding generation which has explained the war experience from its own standpoint, based on its values and the current situation.

According to Shpagin, during the war and its horrors people felt closer to God and to existential questions. The war offered people a real enemy, not the "invented" enemy of the 1930s. ${ }^{153}$ The war always played a significant role for the state and for the nation. One can see that the tragedy brought people together in commemoration and gave them a reason to be proud of their country. It strengthened a shared patriotism, not on the basis of ideology, but instead on the basis of wartime sacrifice, suffering, and victory. Thus it is necessary to address the phases that shaped the narrative of the war during the Soviet and post-Soviet eras and how they were reflected in films. It is also important to examine common themes between the two eras that have retained relevance and why these themes remain so significant today.

The Second World War exists in modern Russian culture in the form of "myth," in the creation and sustaining of which the filmmakers played and are still playing an important role. ${ }^{154}$ Talaver explains that the war can be described as both a "grounding myth" and a "defensive myth", since it also laid the ground for the new nation and mobilized a whole society to defend the country. ${ }^{155}$ The "myth" is here seen as a story that transfers values particularly important for the nation. Russian cinema critic and historian Shpagin calls the war

\footnotetext{
152 Emden and Midgley, Cultural Memory and Historical Consciousness, 23.

153 Шпагин, Великая Отечественная Война в Российском Кинематографе.

${ }^{154}$ Birgit Beumers, Directory of World Cinema : Russia (Bristol: Intellect Ltd., 2010); Catherine Merridale, Ivan's War: Life and Death in the Red Army, 1939-1945 (New York: Macmillan, 2006); Талавер, “Память о Великой Отечественной Войне," 4.

155 Талавер, “Память о Великой Отечественной Войне,” 17-22.
} 
also a "religion"; he states that during the Soviet era, the Second World War was a temple and a substitute for God. ${ }^{156}$

Similarly, Youngblood sees war as a significant theme in both Soviet and Russian films. War themes proved to be very popular and had large audiences, which also suggests that they had strong influence on society. She offers several reasons why war had an important place in the Soviet cinema: the USSR was founded during the civil war, war helped to maintain authoritarian rule by showing that the state is surrounded by enemies, the state's rhetoric was by nature militaristic, and war films offered an opportunity to implant the official history through entertainment. She also explains that war became a way of life and worked as an "organizing principle" for the state. In Youngblood's opinion, "the war movie could never be "only a movie" during the Soviet era, since the film industry was under state control. However, films have the power of both "reinforcing and undermining" the official history, given the complexity of the film as art, as well as the state's ability to ban certain films. Accordingly, "complicated cultural products" are much harder to contain under censorship. Not all political films were propaganda and many filmmakers planted in them images that were "complex and ambiguous." 157

Still, what made war films popular among both the producers and people was that war stories are easily told with the help of the classical narrative structure which makes them easy to comprehend. As Youngblood explains, the story is "character-centered and actionoriented" and "the plot consists of three parts: the status quo (peacetime) is established; it is then violated (invasion); and finally, set right (victory)." A linear narrative with minimal "flashbacks" or "crosscuttings" and the realistic style makes the story also easier to follow. Youngblood draws out two main story lines in the Soviet war movie: the "mission" (the

\footnotetext{
156 Шпагин, Великая Отечественная Войнав в Российском Кинематографе.

157 Youngblood, Russian War Films, ix, 3-4.
} 
collective goal) and the "personal" (individual leaders or comrades) and stresses that in contrast to the "American-style happy ending", the Soviet "happiness" meant that heroes usually died and became martyrs. ${ }^{158}$

Cathrine Merridale asserts that the post-Second World War canons as well as the "myth" were actually founded before the war began. The war movies in the 1930s not only motivated soldiers to fight, but also influenced the personal memories of the soldiers after the war was over. The heroic films that were shown created figures that soldiers could relate to during the war, and as veterans they wanted to resemble the fictional heroes they saw in the films. Both Merridale and Talaver acknowledge the importance of portrayals of war with the fascist enemy prior to 1941 , since it made it easier to fight the enemies that people were already aware of and to strengthen the anti-fascist narrative. ${ }^{159}$

If during the 1930s war was portrayed as a "bloodless war" (война малой кровью), then the actual war brought "suffering, tears, fear, humiliation, losses" to the screens. ${ }^{160}$ Carleton, analyzing the Soviet and Russian war films from the perspective of annihilation narratives, states that the image of total destruction, which is very characteristic for almost all war movies, can be dated back to the Second World War. In his opinion, the main war narratives before the war also represented "ultimate sacrifice" and "supreme opportunity to die for the country," but the actual war that generated enormous human losses changed the war experience to one of "total annihilation." The war "shattered traditional paradigms for troping the dead and has made it the backdrop to any and all contemporary discussions of war and death in Russian culture."161

\footnotetext{
${ }^{158}$ Youngblood, Russian War Films., 5

${ }^{159}$ Merridale, Ivan's War; Талавер, “Память о Великой Отечественной Войне,” 17-8.

${ }^{160}$ Талавер, "Память о Великой Отечественной Войне," 17-8.

${ }^{161}$ Gregory Carleton, "Victory in Death: Annihilation Narratives in Russia Today," History \& Memory 22, no. 1 (2010): 135-68, 135-38.
} 
Shpagin agrees with Carleton, and says that sacrifice for the motherland was indeed the main popular goal. He says there was no regular death, only death with a "capital letter," which means to die for one's country. The war distinguished good people from bad. It was the ultimate test for people, and brought out their true nature. ${ }^{162}$ The distinction between good and bad is on the other hand a simplified understanding of a patriot and an enemy, since it is brought to a viewer the context of fighting the German invader or surrendering to him.

Shpagin also sees that war experience brought people closer to God. Although they did not know what God was; they still felt it intuitively and unconsciously. During the war, there appeared an "existential beginning" in the films that was in direct conflict with state ideology. It made people ask existential questions, and these questions are all directed to God. Many war films can therefore be characterized as a "procession" (Крестный поход), steps that people need to take to get to God. There might not even be religious images or symbols, or the symbols are turned upside down, but one can still feel the influences of Christianity in death and sacrifice. The Soviet "myth" of the war was therefore one of tragedy, but also purification. These religious connotations were also used afterwards. For instance, Shpagin notes that in the film of Sergey Bondarchuk They Fought for Their Country (1975), the main character crosses himself and asks God why he was punished this way. ${ }^{163}$

Similarly, Youngblood considers the wartime films very significant for overall Soviet cinema, especially since there was greater artistic freedom in the production of these films. She states that one of the most important films at that time was a documentary: The Defeat of the German Fascist Troops near Moscow (1942). According to Youngblood, the film brought out four major themes that were products of Russian culture, but also influenced strongly future narratives: (1) "a holy war to save the motherland" (2) "a people's war" (3) "a battle to

\footnotetext{
162 Шпагин, Великая Отечественная Война в Российском Кинематографе.

163 Ibid.
} 
the death" and (4) "a war to save Russian civilization." At the same time Stalin defined the war as a Russian endeavor, in order to mobilize the larger part of the population and therefore one can see the influences of this essentially political decision in the wartime films. These themes support Youngblood's understanding that "Soviet cinema was 'Great Russian' in its orientation." $" 164$

Wartime also contributed images of women as heroes or warriors to Russian cinema. Although, the image didn't last long on the screen, it still influenced films in later periods. The portrayal of women in the films goes hand in hand with the need to mobilize women and incorporate them into defense of the state. Feminine symbols, however, seem to be important, since the Russian word "motherland" (rodina) started to replace the word more commonly used in Soviet context, "fatherland" (otechestvo). The state is therefore associated once again with Russianness and the religious tradition of Christian motherhood. ${ }^{165}$

In the last year of the war, Stalin strengthened censorship. Women did not receive much attention after that; instead the Red Army assumed a central position. ${ }^{166}$ The state started to dictate how the war should be portrayed to the smallest details. For instance, in her work about the Second World War memory in Russian films, Alexandra Talaver brings out the official directive from 22.10.1943 that prescribed how to present war in films. First, it was essential to speak about the loss of lives, but it also prescribed details, such as: soldiers' equipment in winter conditions, attrition in the process of continuous battles, the hardships of digging the trenches, carrying the weapons in difficult places (forests, swamps), the difficult work of nurses and doctors, etc. ${ }^{167}$ Thus, artistic freedom was quite strongly regulated in the most minute details.

\footnotetext{
164 Youngblood, Russian War Films, 2, 55-60.

165 Ibid., 60-5.

${ }^{166}$ Ibid., 71-8.

167 Талавер, “Память о Великой Отечественной Войне,” 18.
} 
From this point on the films reflected, to a greater of lesser degree, political changes within the Soviet state. During the last years of the war one can already notice some particular developments in the war narrative directed to people through films. Youngblood underscores that there was also a place in these films for the current concerns of society, for instance, how to welcome home injured veterans. ${ }^{168}$ The films aimed to lift the morale of people or instructed them how to deal with the consequences of the war.

The narratives that were created after the war lasted until the death of Stalin. In this immediate postwar narrative the achievements of wartime were ascribed mainly to Stalin and the victory of the war was closely connected with the cult of Stalin. ${ }^{169}$ Similarly, the first films of that era stressed that the war was won by the generals who were guided by the "wise Comrade Stalin." After a while, the generals were set aside and the accomplishment was Stalin's alone. According to Youngblood, there were usually two types of heroes: dead people and Stalin. Thus, the films from this time may have influenced the overall emphasis on death, as the true heroes of the war usually fall on the battleground. There was also an emphasis on ultimate victory, as individual suffering was marginalized. ${ }^{170}$

The The Fall of Berlin (1949) is, according to researchers, one of the characteristic films of that era portraying Stalin as a wise "teacher" and "advisor" to the generals. ${ }^{171}$ According to Taylor, this film promoted the cult of Stalin and justified the post-war division of Europe and the developing Cold War. The Fall of Berlin also tries to further shape the postwar official narratives in its portrait of the Yalta Conference: the audience sees that Churchill was the main obstacle to a quick end to the war, whereas Stalin is a true statesman who tries

\footnotetext{
168 Youngblood, Russian War Films, 79.

${ }^{169}$ Kathleen E. Smith, Mythmaking in the New Russia: Politics and Memory during the Yeltsin Era (Ithaca: Cornell University Press, 2002), 85; Merridale, Ivan's War, 362; Kudryashov, "Remembering and Researching the War: The Soviet and Russian Experience," 94-98; Brandenberger, National Bolshevism., 241.

${ }^{170}$ Youngblood, Russian War Films, 5, 82, 90.

${ }^{171}$ Ibid., 99-101; Талавер, “Память о Великой Отечественной Войне,” 22; Шпагин, Великая Отечественная Война в Российском Кинематографе; Taylor, Film Propaganda, 99-122.
} 
to encourage the allies to help him achieve peace. Taylor states that the film is a good example of how the recent past was used in order to "promote a particular interpretation of the present." ${ }^{\prime 72}$ In addition, such films followed the narrative taught in the schools. For example, Wertsch points out that the recommendations for schools from 1949 prescribed the portrayal of Stalin as the wise leader who outwitted the Germans. ${ }^{173}$ The film therefore strengthened the master narrative by reinforcing it with visual elements.

Although, Stalin's cult disappears soon after his death, other narratives remained constant throughout the Soviet era. This represents once again the search for a usable past. Since the world order needed to be legitimized and reasons provided as to why previous allies became enemies, the nation had to know that the allies were actually hindering peace. It also supports the interpretation that the Soviet Union was the major player among the allies in liberating Europe from Nazi Germany.

After Stalin's death, there was a break from the Second World War movies. According to Shpagin, the filmmakers were confused during that time and did not know how to portray the war. ${ }^{174}$ Only after Khrushchev's Secret Speech they were able to understand the present position towards the war. Youngblood states that "during the de-Stalinization, the Stalin cult was replaced by a cult of the Great Patriotic War." The films featured individual sufferings but heroization also remained prominent. They also "re-examined" the previous narrative of the Great Patriotic War and "challenged" the sole role of Stalin in the victory. The Thaw contributed to postwar Soviet cinema world-famous Second World War films such as The Cranes are Flying (1957, Kalatozov), The Ballad of a Soldier (1959, Churkhrai), The Fate (or Destiny) of a Man (1959, S. Bondarchuk), and Ivan's Childhood (1962, Tarkovsky). According to the scholarship, the films on historical themes were mainly produced by young

\footnotetext{
172 Taylor, Film Propaganda, 100-22.

${ }^{173}$ Wertsch, Voices of Collective Remembering, 78.

${ }^{174}$ Шпагин, Великая Отечественная Война в Российском Кинематографе.
} 
directors who started their careers during the Thaw, since the older generation of filmmakers was not willing to accommodate itself to the sudden changes in the official narratives. ${ }^{175}$

In the Brezhnev era the war films were seen as particularly important in building patriotism and Soviet identity. Since the Second World War "cult" also reached its peak during that time, it is understandable that filmmakers had to accommodate the demands of both the state and people, and this caused the rapid growth in war film production. Although the Party still denounced Stalin's cult of personality, the Brezhnev leadership was not very satisfied with the new portrayal of the Second World War during the Thaw; it did not promote patriotism and confidence in the Soviet army. Similarly, the ambiguous art films were difficult to understand for a larger audience, who preferred "Hollywood style" stories that would make them "feel good about the past sacrifices". According to Youngblood, the "Stagnation era" films approached the Second World War in very different ways. Although, Brezhnev preferred "straightforward" art and wished it to serve the state's goals, some filmmakers continued the "low key questioning." This era contributed large-scale combat films that almost always took place on the ground (Stolper's Retribution, 1967, Ozerov's Liberation 1968-71). A new genre was introduced in the form of the thriller, and Soviet spies were added to the list of heroes (Sasov's Shield and Sword, 1967-68). ${ }^{176}$ The overall approach to war in the films of the 1970s, however, did not reflect the cult of war that society still embraced. According to Youngblood, "[F]ilmmakers peeled away the shiny surface of the war cult to reveal the blood, grit, fear, and desperation that lie below." ${ }^{177}$ These movies may not have had such an influence on the larger audiences, due to their poor reception since large-

\footnotetext{
175 Beumers, Directory of World Cinema, 54; Youngblood, Russian War Films, 106, 117-18.

176 Youngblood, Russian War Films, 140-64.

177 Ibid., 186; Талавер, “Память о Великой Отечественной Войне,” 24-25.
} 
scale combat movies were still more popular. ${ }^{178}$ The artistic films clearly carried on the Thaw traditions and influenced significantly the next generation of filmmakers.

During the 1980s, the Afghan War again changed the interpretation of the Second World War. Youngblood asserts that many films at this time were influenced by the art films that came out during the Thaw. For instance, Yevtushenko's Kindergarten continued the topic or forms established by Ivan's Childhood and The Ballad of a Soldier. Here, the vulnerability of children in war gained attention, reflecting the ongoing discussions that took place about the same topic in society. One can see that filmmakers approached the war differently; the war was now seen more and more from pluralistic perspectives, children and women in combat were brought to the screen, and there was also more room for relationships and romance. ${ }^{179}$

For the fortieth anniversary of Soviet Union's victory in the Second World War in 1985, one can see many contrasting approaches from the filmmakers; on the one hand Ozerov came out with the "Brezhnev-Stalinist" film A Battle for Moscow (1985), on the other hand, there is Mkrtchian's Legal Marriage (1985) that connects to the films from the Thaw. In the same year an antiwar film was also released - Come and See (1985) by Klimov. It called for peace and showed no heroes or glory. Interestingly, it was very popular and was named the best film at the Moscow Film Festival. One can see that the development in society toward openness had already started. Youngblood points out that before glasnost Lev Anninsky wrote an article about the Second World War, stating that the war in the films was not being portrayed as it was, but what was in the collective memory. The war was a "legend" and therefore filmmakers had to bring new paradigms to people. Anninsky also proposed that the

\footnotetext{
178 Youngblood, Russian War Films, 186-87.

179 Ibid., 188-93.
} 
new generation of filmmakers who did not have the experience of war themselves should bring in their own interpretation. ${ }^{180}$

The Openness (glasnost) of the late 1980s continued to bring out all the topics that were not dealt with in earlier films. Suddenly, viewers had to deal with very complex issues that did not coincide with the master narratives they were fed throughout the post-war period. The penal battalions, negligence of the commanders, starving, unprepared and ill-equipped soldiers, the destiny of the POWs, prisoners as "suicide troops" - all found their way to the screen by the end of glasnost. The most intriguing in this regard was the documentary film Penal Soldiers (1990) by Lev Danilov that unveiled a topic kept secret for decades. ${ }^{181}$ According to Carleton and Wertsch, such topics were still difficult to process for people who were taught to respect the memory of the war. The open discussion about the war horrors opened up public debates and the directors as well as historians were accused of falsifying history. ${ }^{182}$ These debates are still taking place, the revelations that started during the Gorbachev era continue to influence society. As Medinsky demonstrates in his book The War. The Myths of the USSR. 1939-45, the number of dead that Gorbachev proposed, as well as the role of the penal battalions in war, is once again disputed. ${ }^{183}$ The authorities try to turn back the clock and deny the mistakes that Soviet leaders made during the war, and as Youngblood states, the war is still a "minefield for Russian historians." 184

In the 1990s there was a tendency to continue with some revisionist movies about the Second World War, however, due to financial problems in the film industry, the overall production of films fell significantly and since the new regime wanted to distance itself from

\footnotetext{
${ }^{180}$ Ibid., 193-97.

${ }^{181}$ Ibid., 203; Carleton, "Victory in Death," 142-43.

182 Wertsch, Voices of Collective Remembering, 89; Carleton, "Victory in Death," 141.

${ }^{183}$ Мединский, Война. Мифы СССР. 1939-1945.

${ }^{184}$ Youngblood, Russian War Films, 218.
} 
the history of the Soviet Union, the topic was not very important in society. ${ }^{185}$ Youngblood points out that the fiftieth anniversary of Victory Day was met with sorrow, not pride, because the truth about the Second World War was difficult to digest for the larger population. ${ }^{186}$ With taking away such a strong "myth" as the Great Patriotic War, people had nothing to lean on in its place. As Wertsch states, however, the transformation of the "official" collective memory and the disappointing information about the "sacred" war were in fact working counter to what was expected among the larger population. Since people were taught by their experience with Soviet mass media not to trust everything that is portrayed, many people thought that truth was actually opposite to what was being shown. ${ }^{187}$ It was therefore not a surprise that the memory and the "sacrality" of the Great Patriotic war were once again revived successfully by the authorities of the next era.

According to Wood, Putin stated that the war was "a genuine achievement of great power," implying that the president wished to restore people's respect for their own country. ${ }^{188}$ Mikhaleva, however, places Putin's constant invoking of the past in a much wider perspective. She asserts that "[T] he renewed imperial ambitions of an "energy superpower" require legitimization, justifying claims to dominance in the post-Soviet space and offering society release from its post-Soviet inferiority complex." 189 Partly because of these reasons, partly because of popular demand to reinstate the war to its previous position, a number of Second World War films started to appear after year 2000. The war was once again portrayed differently and the interpretations of the war varied substantially. ${ }^{190}$

\footnotetext{
185 Ibid., 204-6; Талавер, “Память о Великой Отечественной Войне,” 26.

186 Youngblood, Russian War Films, 218.

${ }^{187}$ Wertsch, Voices of Collective Remembering, 88-89.

${ }^{188}$ Wood, "Performing Memory: Vladimir Putin and the Celebration of WWII in Russia,"183.

${ }^{189}$ Galina Mikhaleva, "Overcoming the Totalitarian Past: Foreign Experience and Russian Problems," Russian Politics and Law 48, no. 1 (August 2010): 36.

${ }^{190}$ Youngblood, Russian War Films, 218-219; Талавер, “Память о Великой Отечественной Войне,” 27-28.
} 
Talaver sees most of the war movies in 2000s as commemorative, stating the direct connection between film and memory. The films are based on the official Soviet tradition of portraying the war and its interpretation in accordance with the "myth" of the Great Patriotic War. Although the commemorative films also include images that were introduced from the end of 1980s, such as POWs, collaborators, and penal battalions, they are usually used to make the story and characters more interesting. In August of 1944 (2001) and The Star (2002) are seen as commemorative films that follow Soviet canons, but also emphasize the authenticity of the events portrayed. ${ }^{191}$ Youngblood adds that The Star fits well "into the national revival that the Putin government was trying to encourage in the face of declining patriotism and support for the military." ${ }^{192}$ Furthermore, according to Norris, the film "updated the importance of the Great Patriotic War for Putin-era audiences."193

In addition, Talaver explains that during the most recent decades of Russian cinema the "myth" of the Great Patriotic War adds rather than excludes different features. ${ }^{194}$ Accordingly, Youngblood points to films that are innovative regarding the themes they include: The Unknown Blockade (2003) reveals cannibalism and the Soviet authorities' plan to destroy the people during the Siege of Leningrad. Echelon (2006) depicts the mass rape of German women committed by Soviet soldiers. ${ }^{195}$ It is important to emphasize that these topics, as well as the existence of penal battalions, are now highly disputed by the larger population. For instance, the film A Woman in Berlin (2008) that was released just two years after Echelon received negative feedback from the Russian audience because it "distorted history" and presented Russians, who freed Europe from the Nazis, in a bad light. ${ }^{196}$

\footnotetext{
191 Талавер, “Память о Великой Отечественной Войне,” 27-30, 45-46.

192 Youngblood, Russian War Films, 225-26.

${ }^{193}$ Stephen M. Norris, "Packaging the Past: Cinema and Nationhood in the Putin Era," KinoKultura, 2008, http://www.kinokultura.com/2008/21-norris.shtml.

194 Талавер, “Память о Великой Отечественной Войне,” 42.

${ }^{195}$ Youngblood, Russian War Films, 223.

${ }^{196}$ Михаил Трофименков, “Искупительные Хроники 'Безымянная - Одна Женщина в Берлине’ И Другая Новая Правда о Войне (In English: Redemptive Chronicles Anonymous -A Woman in Berlin and the Other
} 
Moreover, in the current situation and the passing of the new law to protect the memory of the Second World War, these kinds of alternative accounts will probably not be allowed.

The new era also added Orthodox religion and Russian nationality to the memory of the Second World War, which established a connection with the Russian imperial past. ${ }^{197}$ Although one can argue that these topics were also perceivable during the Soviet era, Shpagin notes that the motifs that one can interpret as religious are now even stronger. ${ }^{198}$ In addition, Youngblood sees Soviet cinema as "Great Russian" and Brandenberger considers the overall Soviet identity as Russian in nature. ${ }^{199}$ Thus they are stating that religion was never absent from the commemoration of war, even if the religious images did not make it to the screens. Now, however, the features that one could only sense in the Soviet era films are visible and openly addressed. Talaver asserts that there are not only religious symbols, but that the church plays a central position in films like Pop (2009), where a religious leader, Father Alexandr, is favorably portrayed. ${ }^{200}$ Religious themes and symbols in contemporary films are not only the result of reestablishing a new Russian identity on the basis of Orthodoxy, but are also due to changes in the war commemoration practices during the 1990s. The inclusion of the Church in the commemoration of the war can be called an "invented tradition," a concept proposed by Hobsbawm, who said that usually the traditions that people consider old, are in fact quite recent. ${ }^{201}$ During the Soviet era, one's religion was not displayed; however, since the Church is now a very important part of the war commemoration, one can see that films indeed leave an impression that it was also a part of everyday life during the Soviet Union. Therefore, the

New Truth about the War)," Коммерсант, June 19, 2009, http://www.kommersant.ru/pda/kommersant.html?id=1185828.

197 Youngblood, Russian War Films, 221; Талавер, “Память о Великой Отечественной Войне,” 42-46.

198 Шпагин, Великая Отечественная Война в Российском Кинематографе.

${ }^{199}$ Brandenberger, National Bolshevism, 2-33; Youngblood, Russian War Films, 2.

200 Талавер, “Память о Великой Отечественной Войне," 42-46.

${ }^{201}$ Eric Hobsbawm and Terence O. Ranger, eds., The Invention of Tradition (Cambridge: Cambridge University Press, 1992), 1; Kudryashov, "Remembering and Researching the War: The Soviet and Russian Experience," 86. 
tradition that started twenty years ago seems to be older than it actually is, and people themselves start to acquire the new memory narratives.

The parallels between memory and film, as one can see, are consistent. As personal memories vary, depending on the individuals, so too do the films show various perspectives, covering not only the state's official history, but the lives of ordinary people. If one also acknowledges the screenplays that may have been either inspired by or drawn from personal memories, the connection is even stronger. In this regard, one can argue that all the films can be compared with memory, since memory is selective and reflects the present situation. Moreover, no one can claim to portray the authenticity of events, since they have been exposed to cultural memory. Most important, however, is the emphasis on the interpretation of the younger generation because it clearly shows what resonates in society.

This thesis aims to complement the work already done in the field of Soviet and Russian films by analyzing the contemporary film Stalingrad (2013) in wider Russian cultural and social context. Since the film is relatively new, it has received attention only from film critics and has not yet been examined in the larger context of Soviet and Russian war films. The approach to film analysis is holistic and is based on the assertion that film is not only connected to a contemporary artistic environment or traditions of a genre, but to a larger cultural and historical context.

Furthermore, this thesis looks at how the film tries to engage the public in the story and thus influence the society. Therefore, the analysis concentrates also on the narratives, symbols and visual elements used in the film Stalingrad, to understand the messages that are given further. The topic of this thesis is very timely, since one can observe changes in both developments of a war film genre, as well as the increased control over artistic freedom. This 
in turn shows that films are considered to be influential means of communication also by the authorities. 


\section{CHAPTER THREE: CULTURAL MEMORY AND PATRIOTISM IN THE}

\section{FILM STALINGRAD}

Stalingrad tells an epic story about the Battle of Stalingrad. There are two trajectories in the film: the first is dedicated to five Russian soldiers and a girl named Katya who have to protect a strategically important house in Stalingrad from the enemies. The second trajectory shows a complicated love story of German captain Kahn and the Russian woman Masha. The film speaks about the lives of different people during constant military encounters between Russians and Germans.

This part of the thesis is dedicated to the film's analysis from the point of view of cultural memory. Different elements of the film will be under observation, including production, authors, technical solutions, narratives and symbols portrayed. Discourse analysis applied will involve various disciplines as well as methods, that will allow us to see the ways the film influences the understanding of war in society and fosters patriotism.

\section{Background information}

Stalingrad was directed by Fedor Bondarchuk, and its screenplay was written by Ilya Tilkin and Sergey Snezhkin based on Vassili Grossman's novel "Life and Fate." The film was released in September 2013 in Volgograd (previously Stalingrad). It is one of the best-selling feature films, not only due to the topic, but also because of its new technological approach: it is the first 3D movie made in Russia. One can say that from the perspective of cultural memory, the place where the film was released as well as the year is significant. This film has 
the ambition to influence its audience, since it is framed by all other festivities connected with the celebration of $70^{\text {th }}$ anniversary of great victories like the battles of Stalingrad and Kursk. Moreover, the film was released in the place where the battle actually occurred, thus the connection between film and real life is strengthened. Similarly, it was conscious choice to have the TV premier on the most important date connected with the Second World War for Russians, Victory Day on May 9. ${ }^{202}$ In many ways it resembles the Soviet tradition to make Second World War anniversary films (for example Ozerov's films). The film thus serves as a "trigger" for cultural memory and one of the ways to commemorate the event by pointing out that this was a turning point for nation's history. Looking at this in the context of contemporary political developments that strive to promote the Second World War for fostering patriotic feelings, as well as to censor the negative portrayal of the war, and acknowledging that the film was supported by the Russian Ministry of Culture, this may also be seen as one of the ways to communicate the "politically correct" interpretation of the event. ${ }^{203}$ As one can see, Russian cinema critics have also pointed this out, seeing the film as "the peak of Russian patriotic absurd," "implementation of the social order," the need to show the "heroic acts," the portrayal of "true history," etc. ${ }^{204}$

One way how the audience is attracted to the cinema is through the use of new technology. This is the first Russian 3D film, the most expensive film in the Russian history, and since it was supported by the government, one can see that the use of new technology for representing an historical event is considered important both by the state and by the

\footnotetext{
202 “9 Мая Состоится Телепремьера Фильма Федора Бондарчука ‘Сталинград’ (In English: The Premier of Fedor Bondarchuk's Film ‘Stalingrad' on TV Will Take Place on May 9),” Российская Газета, Мау 8, 2014, http://www.rg.ru/2014/05/08/stalingrad.html. 203 “Владимир Мединский Озвучил Результаты."

204 Роман Апрелев, “Фильм Сталинград Играет на Одном Поле с Человеком-Пауком (In English: Film Stalingrad Plays on the Same Field with Spiderman)," October 14, 2013, http://www.vlg.aif.ru/culture/art/946542; Архангельский, “Приказано Выжать (In English: Ordered to Squeeze It Out).”
} 
producers. ${ }^{205}$ Their effort was effective, since Stalingrad became also the highest-grossing film in the history of Russia; there were over 6 million viewers who all shared the same story of the battle of Stalingrad in 3D format. ${ }^{206}$ The number of 2D film viewers, who either did not have enough resources or time to go to cinema, increases the total number by additional millions, but this is impossible to estimate since the film is freely available on multiple websites.

One can say, however, that the film itself became an important event in Russian cinema history: different polls show that it was considered the best film of the year. ${ }^{207}$ Furthermore, the opinions of the Second World War veterans was overall positive, some consider the film as truthful and think that this should be promoted among youth to teach them about morality and their past. ${ }^{208}$ Looking through different comments that the film received from viewers, one can make clear distinctions: viewers usually give positive feedback when they pay attention to the parts of the film that influence emotionally, such as story and technological solutions. On the other hand, those viewers who have higher expectation and analyze it from the artistic point of view criticize director's work, special

\footnotetext{
205 “Фильм Федора Бондарчука Сталинград - Рецензия И Отзыв (In English: Fyodor Bodanrchuk’s Film Stalingrad - Reviews and Feedback)," Собака, September 23, 2013, http://www.sobaka.ru/rnd/city/cinema/18403.

206 “9 Мая Состоится Телепремьера Фильма Федора Бондарчука Сталинград (In English: The Premier of Fedor Bondarchuk's Film Stalingrad on TV Will Take Place on May 9)”; “Владимир Мединский Озвучил Результаты."

207 “Лучшая Телепередача, Телесериал и Кинофильм 2013 Года (In English: The Best TV Programme, TV Series and Film in Year 2013)," Levada, February 11, 2014, http://www.levada.ru/11-02-2014/luchshayateleperedacha-teleserial-i-kinofilm-2013-goda; “Итоги Года: Люди, Программы, Фильмы (In English: Results of the Year: People, Programmes, Films)," ВЦИОМ, December 26, 2013,

http://wciom.ru/index.php?id=459\&uid=114659; “Фильмом Года Названа Работа Российского Режиссера Ф. Бондарчука Сталинград (In English: F. Bondarchuk's Stalingrad Is the Film of the Year ),” ВЦИОМ: Итоги Года: Люди, Программы, Фильмы, December 26, 2013, http://wciom.ru/index.php?id=459\&uid=114659; “Какие из Этих Фильмов Вы Порекомендовали Бы Посмотреть Своим Родственникам, Друзьям, Знакомым? (In English: Which of These Films Would You Recommend to Your Relatives, Friends and Aquintences?)," ВЦИОМ, June 8, 2014, http://wciom.ru/zh/print_q.php?s_id=966\&q_id=66429\&date=08.06.2014.

208 “Волгоградские Ветераны Поставили 'Четверку’ Фильму 'Сталинград' (In English: The Veterans in Volgograd Gave 'Grade Four (B)’ to the Film Stalingrad),’ РИА Новости, September 28, 2013, http://ria.ru/culture/20130928/966517900.html.
} 
effects and the plot. ${ }^{209}$ Thus, the film clearly demonstrates that the emotional side is very important in the reception of the messages it trasmits.

When a historical theme-based film becomes a blockbuster, one has to acknowledge that it has an effect on the group's perception of history as well as on the ideology the film communicates. Furthermore, its influences are even stronger when the story shown does not portray the event in a nuanced way, but transfers a conventional interpretation. Thus, using Stuart Hall's terminology, the reception proves that the film is decoded in the dominanthegemonic code, because it uses widely accepted connotative codes for portrayal of the Second World War.

Since individual memory cannot be separated from cultural memory, the personal experience and connections to the war and previous war films of the Director Fyodor Bondarchuk seem especially important, since they show the views of a participant in this cultural context. We can see that the director has a personal involvement with the war: his father Sergey Bondarchuk, the famous Soviet film director, was an actual participant in the war. In addition, Fyodor Bondarchuk was a student of Ozerov, who made three great films about the Second World War, all for the great anniversaries, among others Stalingrad (1990), in which young Bondarchuk played a leading role.

Fyodor Bondarchuk himself has directed a film about the Afghan War, $9^{\text {th }}$ Company (2005), that was seen also as a patriotic film and became very popular in Russia. ${ }^{210}$ However, one can say that the previous film was somewhat critical of army and thus it is not well integrated to the narrative of Russia as "the Great Power." One of the screenwriters, Sergey Snezhkin, previously directed the TV series The White Guard (2012) that generated controversies in Ukraine, was consequently banned there and the director was accused of

\footnotetext{
${ }^{209}$ See more: "Мегакритик," accessed April 9, 2015, http://www.megacritic.ru/film/2395.html; "КиноПоиск," accessed April 9, 2015, http://www.kinopoisk.ru/film/468196/press/.

${ }^{210}$ Norris, "Packaging the Past."
} 
transforming Bulgakov's novel into an anti-Ukrainian story. ${ }^{211}$ Through this example, one can see that the controversies surrounding the Civil War, where Red and White Russians where fighting each other, are softened by portraying Ukrainians, who fought for their freedom, as the worst enemy. Although, one cannot make many assumptions based on a few previous films, the producers still seem to follow the line of the state ideology by communicating heroic as well as nationalist discourses.

Although Stalingrad is created on the basis of the novel "Life and Fate" by Vassili Grossman, there are few things that could lead us back to the novel: one of the characters, Katya, is taken partially from the book, as well as the location of the main action, the house. $^{212}$ "Life and Fate" is a complicated thaw-era novel that speaks mainly about how people's lives were influenced by war, looking at civilians, their family life and personal sufferings; thus, there is no particular emphasis on heroism. The novel was banned in the Soviet Union also because of its negative portrayal of Stalin. It was first published in the Soviet Union only in 1988, but even then, the last chapter about the antisemitic policies of the USSR was excluded. ${ }^{213}$ One year before Stalingrad (2013) was released there was screening of a TV serial Life and Fate (2012) that was close to Grossman's original novel. One can only assume was this screening of the novel was an inspiration for Bondarchuk, or a way to rewrite the story of victimization into a heroic narrative.

Based on this background information, one can say that there are ways that the production has the ambition to influence the society, with the choice of new technology, and by releasing it in the city that was previously carrying the name Stalingrad. The director, who

\footnotetext{
211 “Почему в Украине запретили Белую Гвардию? (In English: Why Was the White Guard Banned in Ukraine?," Зеркало Недели, accessed December 1, 2014, http://gazeta.zn.ua/CULTURE/pochemu_v_ukraine_zapretili_beluyu_gvardiyu_.html.

212 The resemblence is only in the name, the fact that she is wearing man's outfit and protects the house. [L.R] Василий Гроссман, Жизнь и Судьба (In English Life and Fate), 2nd ed. (Таллинн: Ээсти Раамат, 1990).

213 “Study Center Vasily Grossman. История Рукописи," accessed December 3, 2014, http://grossmanweb.eu/?page_id=413\&lang=ru.
} 
is already famous for patriotic film, is himself an attraction to bring people to the cinema. Furthermore, people influenced by Grossman's controversial novel could see a new interpretation of it that coincides with the current political viewpoint on the Stalingrad battle.

\section{Narrative Analysis of Film}

This analysis concentrates on the main elements that can be related to the influence of the narrative structure on the reception of cultural memory in film. Thus it does not try to analyze all of the components. The structure and the choices made are analyzed also in the framework of cultural memory theory and involve many descriptions in order to illustrate the analysis.

Stalingrad is a full-length feature film that is considered a thriller; however, it also incorporates many static scenes and conversations. The plot is not linear: the film starts in present-day Japan and then takes the audience back to Stalingrad in the autumn of 1942; the film ends again with present day. Talaver asserts that films which have the ambition to influence collective memory try to establish some kind of connection between the past and the present, films may be retrospective (memories), take people back in time (time travelling), or show some kind of biological or social connection between people in the present and in the past (relatives, graduates of the same school). ${ }^{214}$ Similarly, Stalingrad's plot begins in contemporary Japan, where a Russian rescuer Sergey tries to save German youth from a building that has collapsed as a result of an earthquake. In order to keep them calm he starts to speak about his five fathers that were killed during the Battle of Stalingrad. From this point he becomes the narrator of a war story. It is important to note that he speaks not about his own memories, but the stories his mother told him. Thus, one can see that the story claims to be the

\footnotetext{
214 Талавер, “Память о Великой Отечественной Войне,” 42.
} 
authentic representation of his mother's life. On the other hand, it can be seen as a tale or a fiction that is invented by him on the spot, especially when he speaks about situations that did not involve his mother. The direct biological connection with the participants also strengthens ties with the collective memory, stating that the rescuer belongs to the same group and shares the same collective memories. His mother's memories are his memories, although he did not have the same experience. Similarly, contemporary Russians have memories of the Second World War without participating in it. Due to the scale of the Second World War, almost everyone knows someone in Russia who lost relatives in the Second World War, and many people have heard war stories from the primary source. The film Stalingrad accentuates this phenomenon by telling the stories of all of the positive characters (Katya and the Russian soldiers).

Although, Sergey is a narrator of the war story, he is a "point of view" of the film, since he is also one of the characters. Thus, he expresses also his opinion about the importance of the war. Time to time Sergey's voice appears in the war story, telling mostly about the war experiences and previous sufferings of the Russian soldiers and Katya. As already established in the first part of the thesis, emotions are considered to influence the remembering of the story, of the events portrayed, as well as bring relevance into memory. Sergey's intrusion into the war story thus plays on viewers' emotions because he explains the reasons how one or another participant became who they were. For instance, he accentuates the soldiers' previous suffering: how they lost their relatives, how they became cruel, thus eliciting sympathy towards these characters. In the end, the story-teller also explains how important this event is for the whole nation. He points out that his mother wanted him to remember to whom he owes his life. This stresses the fact that the whole nation should remember the event, directly accentuating that the film is one way to commemorate it. Remembering and respecting predecessors, in turn influences patriotism, since it clearly 
accentuates the need to belong to a larger community, to be part of a larger narrative and to be connected to the past. It is not only connected with the political aspirations of the authorities, it is also a common human need.

Let us now turn to the main characters. The war story is divided to two main storylines: about Russian soldiers and Katya (Russian patriots, i.e. "us") and about German captain Kahn and Masha (enemies and traitors, i.e. "them"). This coincides with the classical Hollywood narrative elaborated by Elsaesser and Buck and is easy to comprehend for larger audiences. ${ }^{215}$ Respectively, each trajectory is engaging due to love stories. However, these love stories are different: Katya and five soldiers' love can be seen as self-sacrificing love agape, whereas Masha and Kahn are portraying erotic love. However, one cannot actually see the evolution of these characters during the whole film, it seems like they all possessed their set of values before the battle started.

Katya is the main female character. She lives in the house that is crucial for protecting the frontline. When soldiers enter her house, she refuses to leave and mostly the entire film from this moment on will be concentrated on protecting her and the house. Katya is attributed with numerous saint-like features. Especially important seems to be her name, which is stressed with slow motion by repeating it many times, in order to show the reaction of each soldier to her name (29:05 min). Katya is a diminutive of Ekaterina (Catherine in English), which means "pure." Her character and manners are all supporting the name. ${ }^{216}$ She represents the character that has no flaws, an ideal woman who takes care of the soldiers by bringing them water. Her character coincides with the patriarchic understanding of a "good woman" that has Virgin Mary as a role model, thus "pious, loving, humble, hardworking,

\footnotetext{
215 Thomas Elsaesser and Warren Buckl, Studying Contemporary American Film - A Guide To Movie Analysis (New York: Oxford University Press Inc., 2002), 30-31.

${ }^{216}$ Other associations with the name Katya: Christian martyr St. Catherine, Russian wartime song Katyusha (Катюша), Soviet rocket launcher used in the Second World War Katyusha as well as many previous war film heroines.
} 
sweet and obedient." 217 The fact that she becomes a mother without implied physical connection to anyone shows that the resemblance to Virgin Mary is even stronger. Thus, she becomes mother of all Christians, and in this particular film mother of all Russians or the "motherland." This on the other hand is strengthened in the cultural memory by the association with Stalingrad's symbol - "The Motherland Calls" monument to the fallen in the Second World War.

Together with Katya there are five soldiers from different places in Russia: Captain Gromov, Astakhov, Chvanov, Polyakov and Nikiforov. These are the soldiers the audience gets to know and who will be all sharing their life stories with Katya during the battle. Here, these individual retrospective stories of suffering make the whole film seem more authentic, since the stories resemble the narratives that have been passed mouth to mouth. Personal memories make an audience bond with the story-teller and characters, and eventually the film has the potential to rewrite or change the stories that people have heard before. It is important to point out that all of these men are from different places in Russia that are populated by ethnic Russians. Thus, they represent a narrow Russian culture that does not involve other ethnicities, religions nor traditions.

There are signs in the beginning that there is a "love triangle" in the relations between Katya and five soldiers, that the men will start competing with each other for her; however, this intrigue soon disappears. One can interpret the love the men have for Katya is actually love for the motherland, because they are all working together to keep her alive, and sacrifice themselves for her. There is no particular rivalry between the men, and Katya loves every one of them in the same way. The story-teller considers all of them as his fathers and we will not

\footnotetext{
${ }^{217}$ Danijela Majstorović and Inger Lassen, Living with Patriarchy: Discursive Constructions of Gendered Subjects Across Cultures (Amsterdam, Philadelphia: John Benjamins Publishing, 2011), 23.
} 
find out during the war story who is actually his biological father. ${ }^{218}$ One has to understand that they are representing a nation, thus the narrator is the descendant of the entire nation. These soldiers all are killed during the final battle, which portrays self-sacrifice for their country and for their patriotic ideals.

The second female character, Masha is portrayed as a contrast to Katya. Since her name is a diminutive of Maria, one can say that she is mostly associated with Mary Magdalene. ${ }^{219}$ She is raped by the German Captain Kahn, and she is accused of being a prostitute by both Russians and Germans. However, she is not portrayed in a negative way. In some sense her biggest flaw is that she is beautiful and reminds Kahn of his wife. She gives away the food that Kahn brings her to people with whom she shares the shelter; however, they still mock her and do not express any sympathy for her sufferings. ${ }^{220}$ In the end she falls in love with Kahn, who saves her from deportation. However, she is killed soon after by a Russian soldier, who denounces her and calls her a German "mattress." She represents a traitor, and here one can see the morale of the film. She chooses her life over her country, because she is too weak and frightened. But since she is on the "wrong" side, she still will be punished. Comparing Masha's destiny to Katya's, one can see that readiness to bring sacrifices will be rewarded.

The most complicated character we find is Kahn, the German captain. Although he is an enemy and he rapes Masha, one can still feel sympathy for him, because he is not as inhumane as other Germans portrayed. He falls in love with Masha, and tries to help and protect her. His compassionate and philosophical nature is conflicting with the tasks he is expected to fulfill, for example to kill the Jews. Kahn's goal is to conquer the strategically

\footnotetext{
${ }^{218}$ In the final phrases story-teller says that he received his name from his father, Sergey Astakhov. [L.R.]

${ }^{219}$ One can associate her character also with wartime film Rainbow (Радуга, 1943), where there is also a blond well dressed Masha sleeping with Germans and killed by Russians. [L.R.]

${ }^{220}$ This theme is very similar to the film A Woman in Berlin, however, here the roles are turned around: the Russian woman is raped by the German. [L.R.]
} 
important house where Katya and the soldiers live. In the last attack he will be killed together with Russian soldiers.

The location of the main action takes place inside the "house" and although one cannot find any concrete implications to the name, the people who share the Russian cultural context will recognize it as Pavlov's house. The story about this house is a "myth" in Russian cultural memory that represents the heroic deeds of Sergeant Pavlov who resisted the Germans, despite all the hardships of war and limited equipment. The story of Pavlov's house has been relayed from mouth to mouth, there are books and memoirs written about it, it has its place in the history textbooks and there is a monument for it in Stalingrad. However, what is interesting about this heroic story is that originally it also promoted a multinational narrative; among twenty-three soldiers there were nine different nationalities fighting together. ${ }^{221}$ This film on the other hand incorporates only ethnic Russians, thus changing the war narrative according to the nationalist causes which coincide with the present political developments.

The way how the connection with Pavlov's house is made stronger is by incorporating the image of the fountain "Barmaley" (Бармалей) (also called Crocodile, Dancing children etc.) that was located on the square close to the house $(25: 17 ; 01: 47: 08 ; 01: 55: 11)$. This is a monument with six children dancing around a crocodile and holding hands. This image in the film is a replication of a well-known photo made by the Soviet photographer E. Yevzerikhin after a German air raid in August 1942. ${ }^{222}$ This photo is a visual memory of the battle of Stalingrad that is recorded in people's memories. ${ }^{223}$ By employing this image, the product of

\footnotetext{
${ }^{221}$ See more: Лев Савельев, Дом Сержанта Павлова (In English: Sergeant Pavlov's House) (Москва: Военное Издательство, 1960); Лев Савельев, Дом Павлова (In English: Pavlov's House) (Москва: Советская Россия, 1970); Иван Афанасьев, Дом Солдатской Cлавы (In English House of Soldier's Glory) (Москва: ДОСААФ, 1970).

222 “Президент Открыл Легендарный Сталинградский Фонтан ‘Детский Хоровод’ (In English: President Opened the Legendary Fountain 'Dancing Children'),” Российккая Газета, August 23, 2013, http://www.rg.ru/2013/08/23/pamiatnik-site.html.

${ }^{223}$ The fountain is also several times portrayed in the film Enemy at the Gates (2001) and in Russian docmentaries, for example За Волгой для нас земли нет! (2012)
} 
the Second World War cultural memory, the film-makers try to bring the film once again closer to reality and reinforce their interpretation of the war. It is not a coincidence that the fountain is portrayed in the film, because a few months before its release, President Putin personally unveiled the restored fountain in Volgograd. According to the journalists, Putin stressed that this is a special symbol of the battle of Stalingrad that will always remind the nation that there were also losses among children and women. ${ }^{224}$ In saying this, Putin actually dismissed the original meaning of the fountain, and prescribed to it a new importance. Now it commemorates children who died in the war and is thus a war monument.

All in all the story line is despite its genre quite static; there is no culmination or development of events in the film. There are three face-to-face battles between Russians and Germans that can be considered as central elements of the action. One can see that there are causes for these battles; they are all connected with emotions, revenge in particular. For example, the second confrontation develops as a result of burning so-called "Jews" on the square by Germans. Russians run into battle to get their revenge. Similarly, the last battle is motivated partly by Masha's death; this is when Kahn starts to fight with revenge as had the Russians. The simple story-line allows for following the film without much effort; it is thus accessible to large audiences and easily remembered.

The fact that the war story is framed by present time allows one to believe that the event is significant to the current society. The reason why the location is present-day Japan is to show the new aspect of the contemporary patriotism: Russia is developed enough to help the highly modernized country.

\footnotetext{
224 “Президент Открыл Легендарный Сталинградский Фонтан ‘Детский Хоровод’ (In English: President Opened the Legendary Fountain 'Dancing Children')”; “Путин Открыл Воссозданный Фонтан 'Детский Хоровод' в Волгограде (In English: Putin Opened the Restored Fountain 'Dancing Children,'” РИА Новости, August 23, 2013, http://ria.ru/society/20130823/958164742.html.
} 
As already mentioned in the theoretical section - emotions are very influential in regard to reception of and remembering the content. Therefore, it is important to acknowledge that Stalingrad uses an effective 3D technology to portray an event already important in people's lives, to make it even more present in contemporary Russia. We now will show how the audience is involved with the story by bringing out some examples of the technological choices.

There are numerous techniques and special effects that are used to involve people with the film and allow viewers to experience the events together with characters. For instance, combat and raping scenes are clearly accentuated: many of them include slow motion (43:23; 47:22; 53:58; 01:47:41; 01:55:32 min). Similarly, there is no sound before the first battle, thus indicating that something horrible is going to happen next (15:43 min). During the bombing, the sound is muted, imitating the result of deafening explosions $(24: 19 ; 45: 20 \mathrm{~min})$. Bullet movement in slow motion $(44: 45 ; 01: 27: 47 \mathrm{~min})$ or targeting the audience with guns $(9: 53$; 16:00) indicates the ambition to engage viewers and make them feel fear and anxiety. The emotions are also amplified by portraying extensive fire, smoking ruins, abandoned houses, and miserable people.

\section{Film Music}

Music is considered one of the most important ways how to influence people emotionally and we will now examine what choices were made in this regard by the producers.

The music of the film was created by the famous film music composer Angelo Badalamenti, who is mostly known for working with David Lynch. Among his long list of achievements, he has composed music for such films as Blue Velvet, Mulholland Drive and 
Twin Peaks. Badalamenti has received numerous awards and his film soundtracks have been very popular. The choice of a composer of this caliber shows once again that the producer saw the music as a very important part of the film. By influencing viewers emotionally, music plays an important part in both remembering the story as well as the emotions of characters. In the case of Stalingrad, the music accentuates the feeling of sadness, which can be identified as compassion, but there is also beauty behind this sadness that is connected with the heroism of the main characters.

Stalingrad's background music is instrumental; a song with lyrics appears only at the end. When there is music without lyrics, it allows people to engage with the story even more, since they do not have to concentrate on the meaning of the words. When in the end all the action is over, the lyrics are finally allowed. The ending song also has a different function than the rest of the film's music - it has to conclude the story and accentuate what was most important to remember from the film. The ending song is "The Legend" (Легенда), performed by the famous Russian singer Zemfira. The author of the lyrics is Viktor Tsoi who himself is considered to be a legend of Russian rock. He was the song writer who performed in the underground band KINO that was popular in the 1980s. The song is also the last song from KINO's bestselling album "Blood type" ("Группа крови”) that came out during Perestroika. One can only assume that choosing a popular song from the past, instead of creating a new song particularly for this film, was a conscious decision. It was similarly important to select a singer who is well known all around the country because of her emotional depth. The personal memories and emotions that people had from previously listening to the song or the singer are now united with the movie. The song also reinforces the understanding that Second World War commemoration has always been a part of postwar Russian culture. "The Legend" is not connected with the Second World War, it was written when controversies surrounded the Afghan War. However, it still commemorates death and speaks about war experience. One 
can say that here both war experiences have merged and there is no difference in which war somebody fought, it was still a difficult and frightening experience. Another possibility is that the connection between the song and the Afghan War is now challenged as the song becomes unconsciously part of the Second World War commemoration. The memory of a humiliating war is now overshadowed by that of the glorious war, and the ending phrases of the film support this argument, because the story-teller says he is grateful that thanks to his fathers he did not have to experience the war himself, clearly forgetting such wars as the Afghan War and the Chechen Wars.

The music for "The Legend" is very simple, and the calm piano chords are somewhat monotonous and can be interpreted as a processional. The lyrics are in Russian, they are sad and tell the story about the end of a battle. The last words of the song are very significant, and in some sense they influence the way the Second World War should be commemorated:

"Life is just a word - there is only Love and Death,

Hey! But who will sing, if everyone is asleep?

Death is worth living,

And Love is worth waiting for...” [L.R. $]^{225}$

The meaning of the words changes with the context of the film. After watching this film, one understands that love is love for motherland, and death is the greatest sacrifice you make for your country. Without this context, one can have several other interpretations; the patriotic feeling disappears when one looks at these words from the perspective of the Afghan War that coincides with the era the song was written. This song also strengthens Shpagin's assertion

\footnotetext{
${ }^{225}$ In Russian: “А Жизнь - только слово, есть лишь Любовь и есть Смерть, Эй! А кто будет петь, если все будут спать? Смерть стоит того, чтобы жить, А Любовь стоит того чтобы ждать...”
} 
that in the Soviet Union to die for one's country was the highest goal, the greatest thing one could do. ${ }^{226}$

\section{War Narratives}

It is now time to address the narratives that are portrayed in Stalingrad to see in what ways this film repeats or follows the narratives from the Soviet era and recent decades, and which patterns are used to define the meaning of war. Since narratives help people to remember and organize the past, due to the complete set of the story, the narratives that Stalingrad (2013) portrays will be analyzed here. The language of film has two characteristics; one is the repetition of elements, the other the violation of the expectations that the audience has. ${ }^{227}$ Therefore, besides repeating the old narratives, it is important to see what messages are promoted by bringing in new narratives and features. If the narratives are not contradicting the accustomed ones and are conventional, the film reinforces cultural memory and therefore refreshes the narratives that are already in the culture. It is similarly important to see what narratives are new for Russian Second World War cinema and determine the reasons for incorporating these narratives. The film has been made in an era when Russia is not isolated from the influences of Western Second World films, so this analysis also examines the intertextuality and dialog with other national narratives. For understanding that patriotism in Russia is related mostly with the heroic portrayal of war, we will also point out which narratives are left out by the film-makers for not contradicting the widely accepted or preferred war discourses.

\footnotetext{
${ }_{226}^{22}$ Шпагин, Великая Отечественная Война в Российском Кинематографе.

227 Лотман, Семиотика Кино и Проблемы Киноэстетики (In English: Semiotics of Cinema and Problems of Cinema Aesthetics), 42-43.
} 
The choice of the narratives was partly motivated by Youngblood's notion that most Russian Second World War films incorporate the following templates: "holy war to save the motherland," "people's war," "a battle to the death," "a war to save Russian civilization". 228 These narratives coincide with Russian master narratives as well as with elements of Russian patriotism; they are reaffirmed by other researchers, for instance Carleton. ${ }^{229}$ Almost all are distinguishable in Stalingrad. However, in dealing with this particularly film, the narrative "holy war to save the motherland" will be divided into "holy war" and "war to save the motherland," to assure systematical analysis and distinguish two different concepts. The "people's war" narrative will be left out because it is not as strongly present. Most of this narrative will be elaborated in relation to the foreign narratives, because they are alien to Russians. One also has to keep in mind that many of these narratives overlap or they can incorporate different sub-themes, depending on interpretation. In addition, the modernization of contemporary Russian patriotism will be illustrated by incorporating into our analysis Western or foreign narratives that were pointed out by Dobrenko. ${ }^{230}$ In the context of contemporary war films, one should also speak about the forgotten narratives, thus describing what has been portrayed in the recent past, but left out from Stalingrad.

\section{A Holy War}

"A holy war" narrative in Stalingrad shows that God was present, the victory was preordained and Russians sacrificed for the right cause. Here one can see that "holy war" is first and foremost binary opposition between "good" and "evil" or "Christian" and "pagan." When

\footnotetext{
${ }^{228}$ Youngblood, Russian War Films, 55-65.

${ }^{229}$ Carleton, "Victory in Death," 147-59.

${ }^{230}$ Evgeny Dobrenko, "Utopias of Return: Notes on (Post-)Soviet Culture and Its Frustrated (Post-) Modernisation," Studies in East European Thought 63, no. 2 (2011): 159-67.
} 
Kahn motivates his soldiers he says that "God is with us and our God is our Fürher, Hitler," (01:22:11 min) which directly implies the worship of a false god. ${ }^{231}$ Stalingrad also shows that Germans are sacrificing Jews to the ancient Germanic gods (41:33 min) and that they are fighting for the wrong cause (to go to India where all women have six hands) (01:23:01 min). This accentuates that the Russian cause was "holy," because Russians fought for their freedom and protected their country, and also supports the view that the Second World War was defensive war, leaving out the Soviet attack on Poland and occupation of the Baltic States.

In the previous section, the connection between Katya and religion was already stated. One can see that Katya is under the protection of God: she has survived in a house alone despite the heavy bombing and she is the only one who survives this battle in the end. She resembles Virgin Mary by her characteristics. The fact that she will have a son without reference to one particular man, makes the story-teller (Sergey) Christ-like. And the fact that he is a doctor and a rescuer (savior) only reinforces this connection.

In addition to the semantics of Katya's name (which means "pure") and her character, the filmmakers choose to stress her holy features with the help of Russian culture. The first time Katya is on the screen, she is dressed as a boy (stating that she tried not to attract attention as a woman, tried to keep her virginity). Since she is frightened and shaking the soldiers immediately think she is mentally ill (21:07-22:33 min). One of the soldiers even states that mental illness means she is blessed. With that phrase associations spring to mind of

\footnotetext{
${ }^{231}$ It is also interesting that at the same time Kahn gives his speech, there is Stalin's relief portrait in the background. One can only guess if this means that the filmmakers are implying that Stalin was also a false god and thus distancing themselves from the Soviet cult of Stalin.
} 
the representatives of Russian culture who are connected with "the fool for the sake of Christ" (Юродив Христа ради) which means that she is innocent in the eyes of God. ${ }^{232}$.

The Battle of Stalingrad becomes a "holy war" through adding heavy religious subtext: the image of pieta (02:01:20 min), soldiers carrying crosses (08:37 min), onions as symbols for Orthodox onion-shaped domes (30:06; 01:20:04 min), etc. At the beginning of the film, one can see people walking on the water towards the city that is in flames. The camera then turns to the witness of this scene who crosses himself and says a short prayer (06:20 min). His companion, knowing that they are just soldiers who are floating with their equipment to the other side, jokes that these are apostles. After a while he asks, this time seriously, “aren't we all apostles in this war?" This scene is meaningful, because already at the beginning of the film, one can see that the soldiers who fight in the war are sent out on the battleground by God himself so they could perform miracles.

After Russians arrive on the coast they began an attack on the city. The Germans anticipated them and as soon as the Russians were close they blew up traps stored with gasoline. There is a picture of the city gates (with soviet symbols hammer and sickle) and behind the gates there is only fire (15:38-17:10 $\mathrm{min})$. This could be interpreted as the gates of hell and indicate the parallels between hell and the war that the Soviet Union had to experience. One can see how Russian soldiers in flames run out of these gates with vengeful screams and try to kill as many of the enemy as possible before they are dead. These soldiers also symbolize avenging fire angels, and the connection with religion is palpable, since fire refers to presence of God. Moreover, fire could also be interpreted as baptism, or ordeal (Matthew 3:11). The parallel between soldiers and angels is also articulated by one of the

\footnotetext{
232 "Fool for the sake of Christ" is a person who pretends to be a fool, in order to hide his or her true virtues. In Russian literature, for example, Pushkin used this kind of character in his play "Boris Godunov". Here, Iurodivyi (Юродивыци) was the only one who was bold enough to accuse the tsar-impostor directly of murdering the real heir to the throne. All in all, the character symbolizes the only sane person who could deliver the truth to people.
} 
main characters, Polyakov, who calls himself Angel. The soldiers' sacrifice for the country is also rooted in the Christian idea of martyrdom - to reach God through suffering.

As earlier mentioned, Shpagin has argued that the religion returned back to people's consciousness together with the Second World War, because it raised existential questions. ${ }^{233}$ Looking back in time, one can see that wartime film Rainbow (1943) in fact included religion. It is very important to point out that here it is clearly stressed that God is not on the traitor's side ("do not touch God, he is not your God"). And although after the end of the war religious symbols were not particularly present, the cause was still seen as "holy."

The incorporation of religion to war narrative may be also explained through the commemoration of the dead. Religion not only gives the reason for dying, but prescribes how to mourn and allows one to believe in "life after death." The Christian approach to commemoration is deeply rooted in the society through the ceremonial rituals; thus one can understand that in wartime it was magnified. Incorporation of Masha as Mary Magdalene (a woman who mourned Christ) can reinforce the connection between religion and commemoration of the dead, because women are the ones who will be mourning the soldiers lost in battle. Women's role in society is therefore to carry further memory of the war, and memory of soldiers. The story-teller also fits this logic: he is both a medium and physical reminder of the war. Such images of women and their roles also coincide with Putin's conservative politics and the patriarchic society that the state wishes to build.

The portrayal of the Second World War as a "holy war" serves as a tool for nationbuilding and patriotism. As stated earlier, Anthony D. Smith considers that one of the most influential ways to create national identity is to show that a nation has been chosen by God. ${ }^{234}$ Thus, if in the contemporary Russia, religion is the way to channel national identity to people,

\footnotetext{
233 Шпагин, Великая Отечественная Война в Российском Кинематографе.

${ }^{234}$ Smith, "Chosen Peoples," 440-45.
} 
one has to acknowledge that this is similarly important in the case of patriotism because it carries particular values, allows a people to be proud of its heritage and to feel that it has been "chosen by God." In addition, the use of religion is necessary for the support of the state and authorities, because patriotism was initially connected with the faith in the leader - "father" (patris) as the "substitute for God" on Earth. ${ }^{235}$ Russia has always seen the tsar as father of the nation, and as one can see the tradition continued also during the Soviet Union, when Stalin was considered as "father of the Soviet nation." 236 The incorporation of religion to this film is thus a product of culture but it also serves to legitimize President Putin's rule.

\section{A War to Save the Motherland}

Stalingrad's main theme is connected with protecting the homeland, i.e. motherland. The main action takes place in Katya's home and soldiers sacrifice their lives in order to protect her and her house. Both Katya and her house are thus representing the motherland. ${ }^{237}$ Considering that Virgin Mary is a Russian patron saint, as well as "mother of Christians," the theme is supported through various connotations. The way how Katya receives such a heavy symbolic meaning is actually through the above-mentioned love story between five soldiers and her. Each soldier sees her differently and they have a different bond with her; however this love could be described using the ancient Greek world agape: unconditional, spiritual, and self-sacrificing love. They protect her together and do not argue with each other when it comes to her safety. This is further articulated by captain Gromov, who tells Katya that now

\footnotetext{
235 Алексей Швечиков, ed., Православие И Патриотизм (In English: Orthodoxy and Patriotism) (Санкт Петербург: Алетейя, 2005), 68; Smith, “Chosen Peoples,” 440-45.

236 Dobrenko, "Utopias of Return," 164.

237 The resemblence between Katya and motherland (rodina, rodina-mat'). is also pointed out by several Russian cinema critics: Архангельский, “Приказано Выжать (In English: Ordered to Squeeze It Out)”; Андрей Сидорчик, “Сталинград. Охота на Оскара (In English: Stalingrad. Hunt for Oscars)," Аргументы и Факты, November 10, 2013, http://www.aif.ru/opinion/945317.
} 
they are not fighting for the homeland or Stalin, but for her and if she dies, they will all break down (01:07:12 min).

The fact that Katya has a birthday a day before the final battle (01:31:59 min) indicates the birthday of a country; it is further strengthened by the probability that the story-teller was also conceived on this night. Thus the battle also represents the "rebirth" of a nation and coincides with Talaver's notion of "grounding myth." 238

Virgin Mary is a Christian symbol, but the Soviet Union also emphasized the image of "Mother" or "Mother Russia" in numerous war monuments all over Soviet Union erected after the war. Stalingrad's monument "The Motherland Calls!" is the biggest in Russia and also the symbol of the city. According to Kirschenbaum, "mother" in the Soviet era represented the connection between home and nation, between family and state, and in fact, promotion of mother figure appeared during the war, when Leninist-Marxist ideals failed to mobilize the nation. ${ }^{239}$ Thus the concept of motherland was used as a political tool, to foster patriotism and to motivate people during the war.

In addition, Katya's house is also representing homeland. It seems to be very important to protect particularly this house; the whole film is concentrated on the battle for the house, not for Stalingrad. The fact that in the end the soldiers ask their own people to bomb the house while being in it, just to hold the Russian position, can also be interpreted through an historical lens. One has to understand that already the name of the Second World War in Russia stresses the narrative - the Great Patriotic War. ${ }^{240}$ It is the second patriotic war for Russians, the first one was in 1812, when Napoleon tried to invade the Russian Empire. Both of these wars are connected with aggression from a modernized Western army, and both were

\footnotetext{
238 Талавер, “Память о Великой Отечественной Войне,” 17-22.

${ }^{239}$ Lisa A. Kirschenbaum, “'Our City, Our Hearths, Our Families': Local Loyalties and Private Life in Soviet World War II Propaganda," Slavic Review 59, no. 4 (December 1, 2000): 825-27.

${ }^{240}$ In Russian Великая отечественная война; the word otechestvo means "fatherland" and it is a synonym for rodina "motherland." [L.R.]
} 
fought on Russian soil. In the 1812 war, the tactical choice was made from the Russian side to retreat from Moscow and to destroy everything so that the French army would not have the resources to sustain itself. Similarly, in 1941, Stalin was planning to use the same tactics in case of a forced retreat of the Red Army. ${ }^{241}$ Here, destroying the house seems to be the similar to destroying Moscow: it is better to destroy it by "us" than to let enemies benefit from it.

All in all, one can see that to make sacrifices for one's state is one of the main ideas of patriotism. This ensures a loyal nation that is ready to defend the sovereignty of its state and thus mobilizes itself during difficult times.

\section{A War to Save Russian Civilization}

The narrative of "a war to save Russian civilization" is closely linked with the "war to save the motherland" and with the "holy war" as they all stress the ethnic connection with a "mythical past" and are necessary for nation-building. Thus the previously discussed narratives in a way reflect also how the film deals with this narrative. The concept "Motherland" is connected with a particular geographical place, the country of one's mother or ancestors. However, civilization is a wider concept, integrating culture, and as already mentioned in the theoretical section, Russian civilization has its roots in Kievan Rus that is mainly connected with adoption of the Orthodox religion. Therefore, to save Russian civilization means to protect a particular culture, religion, language, way of life, and ideology. Here, the contradiction between Soviet and Russian culture arises: can one say that the Soviet Union was essentially a Russian civilization? It is a widely known fact that the Soviet Union tried to detach itself from pre-revolutionary Russian identity. However, the core of Soviet

\footnotetext{
${ }^{241}$ Margaret Schlauch, "Russian People's Wars in 1812 and 1941-Recent Soviet Historiography," Science \& Society 6, no. 1 (January 1, 1942): 24-25.
} 
culture was still built on previously existing culture. Soviet nation-building or the creation of Marxist-Leninist ideology was done mainly by people who grew up in a Russian cultural context. In addition, Brandenberger notes that Stalin made a conscious move toward Russian nation-building after the war, in 1945, by toasting to Russian people as "the most outstanding nation of all the nations in the Soviet Union." 242 This meant that Stalin saw Russian soldiers as the most patriotic, and defined the war as a Russian conflict. Stalingrad illustrates the "Russian war" narrative: all the participants are Russians, there are no traces of the Soviet “multicultural" society or army, especially regarding Pavlov's house. Even the woman who is picked out by a German because she looks Jewish, says that they are all Russians and there has never been Jews (a narrative that essentially denies pogroms and Stalinist campaigns against Jews). Similarly, one cannot find the representatives of different Soviet nations in one of the first Stalingrad films, The Turning Point (1945), which demonstrates that this narrative could have been rooted since wartime. Based on these movies, one could say that this narrative contradicts both Soviet and Russian master narratives that see the society as multinational and the accomplishments of the state as a result of the contribution from all ethnicities. ${ }^{243}$ At the same time it coincides with the nationalist politics in contemporary Russia.

In addition, "to be civilized" is derived from the word "civilization," which means that the representatives of Russian civilization should be portrayed according to this narrative as advanced, developed, educated, wise, etc. There is a perceived necessity to respond to the portrayal of Red Army soldiers as "uncivilized" or as "savages" and to show that the war was not won by "by coincidence." For example, the portrayal of Russian soldiers in the film $A$ Woman in Berlin (2008) portrayed Russians as animals who did not behave in a civilized way:

\footnotetext{
${ }^{242}$ David. Brandenberger, "Stalin, the Leningrad Affair, and the Limits of Postwar Russocentrism," Russian Review, 2, 2004, 247.

${ }^{243}$ Pääbo, Potential of Collective Memory Based International Identity Conflicts in Post-Imperial Space, 239-40.
} 
they were raping, looting, they didn't have manners etc. This perception coincides with the Estonian master narrative that depicts Russians as uneducated and unorganized. ${ }^{244}$ Furthermore, the image of militarily weak Russians can even be observed in the master narratives of nations that have been under its rule, such as Estonians, Ukrainians and Georgians. ${ }^{245}$ One can see that Stalingrad argues with these perceptions; here there are smart, resourceful, and mannerly people fighting in the war. They are not only good soldiers, but also talented and cultured. For example, Nikiforov is a former tenor who performs an aria on Katya's birthday, and somehow he manages to find a suit to wear in a bombed house for this occasion (01:34:18 min). The images in Katya's house show that Russians are educated: the collection of butterflies (26:10 min), pictures of Russian writers (58:00 min), piano (01:17:35 $\min )$, etc.

The narrative of clever Russians has been there also since the end of the war. There are also similarities with the film The Great Turning Point (1945) that portrayed Russian commanders as wise and strategic. The most important thing that is brought out by contemporary critics of the film The Great Turning Point is that Soviet regular soldiers as well as generals are shown as intelligent people. Thus, it is challenges the view that Germans are culturally superior; instead, the Soviet people have proved that they are a great nation. ${ }^{246}$ Stalingrad (2013) clearly accentuates that Russians are smarter and braver than Germans. The German soldier does what he is told and nothing more. He doesn't think with his own head and this is stressed also by the German army general (30:51 min). Kahn is the only soldier that differs from the rest of his comrades; he is intelligent, and most of all, he is humane. On

\footnotetext{
${ }^{244}$ Ibid., 121; Anneli Mihkelev, We Have Something In Common: The Baltic Memory, Collegium Litterarum 21 (Tallinn: Underi ja Tuglase Kirjanduskeskus, 2007), 37-45.

245 Pääbo, Potential of Collective Memory Based International Identity Conflicts in Post-Imperial Space, 121, $169,219$.

${ }^{246}$ Великий перелом: Выступление Б.Ф.Чирскова по ленинградскому радио о создании фильма Генерал армии.-Из стенограммы обсуждения художественным советом «Ленфильма» фильма Генерал армии (In English: The Great Turning Point: Chirskov's Presentation on Leningrad's radio about the creation of film Army General, - From the stenography of the Lenfilm Council of Artist's meeting), accessed on 21.04.2014 http://www.kinozapiski.ru/ru/article/sendvalues/455/
} 
the other hand, Russians have to be resourceful in order to fight the enemy without the necessary equipment. They even plan one shot so that it would bounce back from the tank and blow up the German headquarters.

This narrative also links all previous regimes in Russia with the help of culture by stressing the longue durée of nation and thus coincides with ethno-symbolist perception of national identity. Its patriotic message also serves to create pride for the national cultural past and for achievements in the cultural sphere.

\section{A Battle to the Death}

The narrative of "a battle to the death" is also linked with previous narratives - to bear sacrifices for the motherland. One can see that every soldier is killed in Stalingrad; they know their fate already in the beginning and do not seem to have survival instincts. During all of the fighting, one can see that although Russians are not well prepared and don't have as many weapons as Germans, they still furiously engage in battles. There are scenes where a Russian soldier goes into a fight with only one pistol as the Germans are pointing machine gun fire at him. There is a lot of physical fighting with vengeful yelling that is made even more emotional for the audience with the help of slow motion.

The fact that all five protagonists (soldiers) die in the end corresponds also to Carleton's observation about annihilation narratives in present-day Russian war films. According to him, the "victory in death" narrative is linked to both historical and religious features. Although the "ultimate sacrifice" also existed in pre-Second World War films, the total destructiveness that one can see in Russian film nowadays began as a result of this war 
experience. ${ }^{247}$ Shpagin adds that the horrors of the war changed something in the mentality of people; they started to ask existential questions and look for the meaning of life. ${ }^{248}$ Martyrdom could be interpreted as an answer to these questions, since it explained that soldiers died for higher cause. Overall, martyrdom seems to be something that is characteristic of Soviet and Russian cinema. Youngblood explains that this can even be seen as a Soviet style of "happiness" - to sacrifice oneself for the state. ${ }^{249}$ The film shows exactly this kind of "happy" ending: five soldiers ask their commander to blow up the building they are currently in so that the army could hold its positions.

As one can see, this narrative is not only connected with the Second World War. Fyodor Bondarchuk also used the same template in $9^{\text {th }}$ Company (2005), thus the narrative now is applicable to more recent wars. In the contemporary context, it carries particular values or lessons, showing that predecessors have made so many sacrifices for the nation; therefore descendants should also protect their homeland.

\section{Foreign Narratives}

Stalingrad does follow in many instance wartime canons, however, since art is connected with cultural context, one can also see influences from previous eras. Films from previous decades that were produced abroad seemed to have an especially strong effect on the director. There are many themes that have never been touched in the Soviet/Russian Second World War films; however they have still found their way to Russian cultural memory.

\footnotetext{
${ }^{247}$ Carleton, "Victory in Death," 135-42.

248 Шпагин, Великая Отечественная Война в Российском Кинематографе.

${ }^{249}$ Youngblood, Russian War Films, 5.
} 
The female characters, as well as narratives surrounding them, are actually quite unusual from the perspective of the Soviet/Russian tradition. Here, they seem to be influenced by Western Second World War films. For instance, the scenes where Masha is raped by the German officer Kahn, turns the film A Woman in Berlin upside down: now it is the German who falls in love with a Russian woman, brings her food and protects her. Overall, noncombatants have not received much attention in Soviet/Russian war movies, therefore the rape scenes seem to be especially strange. This stresses the victimization side, but works also as a reaction to the German portrayal of Russians in A Woman in Berlin.

The portrayal of a German officer, as just another victim of war and of the Nazi regime, is similarly new. Kahn is trying to save Jews because he does not understand why Germans should kill innocent people. He doesn't approve the crimes committed by SS; this is not how the war should look like. He also doesn't approve the fact that Russians are fighting in order to gain revenge since it does not go together with his understanding of warfare. In some ways this film may have been influenced by the Joseph Vilsmaier's Stalingrad (1993), where the protagonist cannot understand the cruelties of the Eastern front. One can see that Kahn regrets raping, and sees that the war made him an animal. Geoffrey Macnab has also observed that the German officer is not portrayed according to Russian traditions: the "strange mix of courage and fatalism matches that of the Russians who are pitted against him."250 Russian cinema critic Archangelskii thinks that the character of Kahn has been included because of humanistic considerations: it is necessary to show that Germans were humans too. However, the functions that are laid on the shoulders of this character do not let him breathe:

\footnotetext{
${ }^{250}$ Geoffrey Macnab, "Stalingrad 3D, Film Review: Visual Dynamism and Plenty of Pedigree," The Independent, February 20, 2014, http://www.independent.co.uk/arts-entertainment/films/reviews/stalingrad-3dfilm-review-visual-dynamism-and-plenty-of-pedigree-9142491.html.
} 
he is a lover, a rapist, the one who thinks with his head and yet does what he is told; he loves and suffers. ${ }^{251}$

The incorporation of Jews into Russian Second World War narrative is, according to the cinema critic Aprelev, alien to Russian cinema. This topic has been "exploited" by the Western filmmakers and finally incorporated into Russian consciousness. ${ }^{252}$ Although, Jews were present in the novel "Life and Fate" that serves as a basis for Stalingrad, one has to acknowledge that during the Soviet era this book was banned. The reason why a Jewish component is added to the narrative may in fact have several explanations. One could be seen as conforming to a global perspective by stressing an already accustomed narrative, i.e. "preferred meaning." The use of a Jewish component would also sell the movie abroad and serve as a tool to introduce the Russian perspective of the Second World War to a wider audience. Second, it was important to draw parallels between Russian and Jewish victimization narratives, to show that not only Jews were victims of Nazi persecution. Simultaneously with Jewish victimhood, there is also a denial of a Russian "Jewish problem" (Jews have never lived there 40:30 min). One could argue that this is trying to minimize the role Jews played in the Red Army and strengthen Russian nationalism. On the other hand it could also show Russian tolerance, by accentuating that they are not making distinctions between different nationalities.

The incorporation of Jews goes hand in hand with the narrative of victimization and suffering. The portrayal of Germans who gather peaceful residents in order to deport them underlines Russians as victims, therefore contradicting the Eastern European narratives that see Russians as perpetrators. The war is seen as resistance to the Nazi invasion and goes hand

\footnotetext{
${ }^{251}$ Архангельский, "Приказано Выжать (In English: Ordered to Squeeze It Out)."

252 Апрелев, “Фильм Сталинград Играет на Одном Поле с Человеком-Пауком (In English: Film Stalingrad Plays on the Same Field with Spiderman)."
} 
in hand with the postwar "liberation" narrative that was imposed on Eastern Europe by the Soviet Union.

There are also many nods to other Western Second World War films. For instance, the fact that the film begins in Japan is a reminder of Pearl Harbor (2001): one can see similar images of airplanes against the background of a flaming sun (01:17-01:25 min). The tale about the Battle of Stalingrad begins in Japan, where Russians help Germans - this tries to bring the US and Russian heroic narratives of war closer, to emphasize that Western powers also celebrate the victory of the Second World War. Japan has never received attention in Russian Second World War films; the main enemy has always been Germany. Here, the scene where Russians are helping two main former enemies of the Allies is also shows how progressive and powerful Russia is: it gives humanitarian help to highly developed countries and thus forgives their aggression. This creates a self-image of a humane, altruistic, modern and civilized nation.

There are also many implied references to Enemy at the Gates (2001), the location of the battle (the house), the fountain, snipers, love story, etc. The overall way of portraying Stalingrad battle and the city in ruins resembles the previous Western film. One can see that the representation of Russians in Enemy at the Gates coincides with the Russian narrative of skillful and talented soldiers; thus there was no need to contradict it, but instead to reinforce it. There is, however a difference in the inclusion of Soviet symbols: the Western version portrays many soviet flags and Stalin's image, while the Russian film tries to avoid them. One can interpret this as distancing itself from the Soviet ideology, at the same time promoting the state's achievements.

The connection with Western Second World War movies is even stronger due to the actor who plays Captain Kahn, Thomas Kretschmann. Kretschmann has acted in numerous 
Western war films, and it is not therefore a coincidence that Bondarchuk chose him to portray the only positive enemy character. Kretschmann has had roles in Stalingrad (1993), The Pianist (2002), In Enemy Hands (2004), Eichmann (2007) and Valkyrie (2008) - most of which are known to the Russian public. Since all of these films portray Nazis in a bad light, they are not taken as controversial in Russia as, for instance, A Woman in Berlin (2008).

One can see that the filmmakers try to engage in dialogue with previous films and to make a statement about what is "true" and what is not. In addition it also resembles Medinsky's (the current Minister of Culture, who supported the film) approach to speak out against the "false" foreign portrayal of the Second World War. This in fact stresses that films are considered important for reinforcing memory of the war. However, the connection with Western films also stresses the parallels between the celebrations of victory in the Allied countries and indicates that Russians should not speak badly about the war, since other countries also portray it in heroic way.

To summarize this chapter, one can see that in the case of the film Stalingrad, the choices made indicate that the film does try to influence people emotionally. The film is easily followed; it has a simple plot, clear positive characters that people can identify with. It also incorporates references to the monuments, stories and images that people are already aware of, thus allowing the audience to make associations. Similarly, if the story follows the line of conventional representation of the heroic war, it also serves as an addition to the previous knowledge about the Stalingrad battle. The 3D technology engages the audience, and the music and narrative strengthen its involvement by playing on the emotions. Functioning together in one film, these components all help to remember the events portrayed and have the potential to influence the interpretation of the war. Since people are emotionally involved and 
the 3D technology amplifies the feeling of "being there" and "participating in it", they are inclined to believe that these things actually happened in the way they were portrayed.

Stalingrad is a cultural product that speaks about the mythical history of a nation, about an event that is foundational to contemporary Russian identity. By showing one story to millions of people the film creates also a bond among the population, which will now have a shared memory of the event. It gives people a necessary "myth" to inspire pride, and it therefore fosters patriotic feelings. One can see that most of the elements of contemporary Russian patriotism do exist in Stalingrad: patriarchic society, modernization, self-sacrifice for the greater cause, heroic nation, religion and nationalism. The superiority of Russians are also accentuated through portraying them as resourceful, talented and civilized. By applying these narrative templates Stalingrad also reinforces patriotism, since it does not only transfer particular values or ideology, but also shows what kind of sacrifices were borne by ancestors.

Analyzing Stalingrad in the context of the development of the Second World War discourses, one should not set aside what narratives are left out. In the case of cultural memory one can see what has been "forgotten." The pluralistic interpretation of the war that started to appear at the end of the 1980s: the penal battalions, negligence of the commanders, starving, unprepared and ill-equipped soldiers, the destiny of the POWs, and prisoners as "suicide troops" are not included. It can be explained by the fact that these narratives were never accepted by the majority and thus did not become dominant or preferred narratives. In addition, the "people's war" narrative of the Thaw era that Youngblood highlighted is not emphasized: one can see women and children living in the basement, but the audience does not bond with them; this mainly serves as an illustration of Masha's suffering and as such is not connected with the Russian or Soviet traditions. The portrayal of civilians and individual suffering of soldiers that appeared during the Thaw era is thus left untouched, except for the life stories provided by the story-teller. 


\section{CONCLUSION}

The aim of this thesis was to show how the memory of the Second World War was used in the contemporary film Stalingrad in order to foster patriotism. This thesis approached the film analysis holistically, by bringing together both contemporary and historical developments of society and culture. This work made a contribution to the existing literature of Russian/Soviet war films as well as to the film Stalingrad critique, but most importantly to the discussions about the role of cultural memory in the contemporary Russian society.

The questions raised in the framework of this thesis addressed eventually an en essential problem: is there a distinguishable Soviet culture and film tradition or can we see Soviet culture as one part of a larger Russian culture? Since the Second World War is an achievement of a different entity, both ideologically and geographically, why is it receiving so much attention in the contemporary society? How is the war itself portrayed, is it connected with the Soviet ideology, and therefore Soviet symbols and war film traditions or does it represent older Russian culture? These questions are important in the overall context of the Russian patriotism, because they explain the core reasons, why particularly this event is chosen and how it is transmitted to a larger audience.

This thesis first gave an overview of the intersections of cultural memory and film in the Soviet Union and Russia. The goal was to show how film has been previously used in communicating the state's values and ideology. This part explained that the authorities knew already during the Soviet era how influential film is in creating national identity and patriotism, especially during a time when most of the nation was illiterate. In the early Soviet Union, Marxist-Leninist ideology was channeled through films to all corners of the state with the help of the "agit-trains." Similarly, in contemporary Russia, the role of films in creating a 
unifying identity is acknowledged: the control over the content and the wish to channel "appropriate" interpretation thus made it impossible to exclude the political factors in the film analysis.

Second, the development of the "myth" of the Second World War was important to address in order to understand, why this event still resonates in the society. Here, the main attention was on the portrayal of the Second World War in the Soviet and Russian films. This part argued that the Second World War, as a story about glorious victory and a heroic nation, is still central to Russian national identity. Based on this part, one can witness that the way the films portrayed the war, influenced people's self image. For example, when during the era of glasnost people were exposed to negative portrayal of Soviet Union/Russians, it started to undermine their faith in the country. When Second World War commemoration stopped for a while on the state level, people were also deprived of their "myth." The reason why Putin's administration reinstated the Second World War as the greatest achievement in country's history was to enhance a positive image of the state among the population. This clearly shows that there is a strong connection between patriotism and the Second World War in Russia, because it is the latest biggest achievement that still exist in the communicative memory and to which the community can relate itself.

The development of the portrayal of the Second World War in films also demonstrated that with time the interpretation of the war was different based on the political situation as well as on the art movements. The research revealed that in Stalingrad the strongest link was created with the wartime narratives that accentuate the war as heroic and defensive. In the film, the soldiers are not shown as humane and suffering as in the thaw era, instead they are true heroes who are able to die for their country and defeat the Nazi army. However, it is necessary to point out that the wartime portrayal was connected with the narratives brought to people before the Second World War and which in turn had been influenced by the pre-Soviet 
era film industry and war narratives in the Old Russian culture. This part demonstrated also the deep roots of cultural memory, pointing out that the film Stalingrad does not follow the recent (Soviet era) portrayal of the Second World War, but instead brings to life previous defensive war narratives that have been used in distant past, for example during the Patriotic War or 1812. Thus, the positive reception of the film Stalingrad is not only the result of the popularity of the topic during the Soviet Union, but because the type of war portrayal is rooted very deeply in the Russian culture.

Furthermore, the most important narrative that the filmmakers emphasize is the "holy war," which is achieved through strong intertextuality with religious narratives. It distances Stalingrad from the Soviet era films, because it accentuates religious symbols and leaves out the Soviet ones. Although, the analysis proved that religion was present also in the Soviet era films and that religion influenced the war narratives, still it was never used so openly and unambiguously.

The film analysis also looked at the different narratives and symbols as the means to foster patriotism. For example, the "holy war" narrative reassures the nation that it has been "chosen" and protected by God. In the "war to save the motherland" Katya symbolizes "motherland," and the love story between her and five soldiers, by extension, love for homeland. To protect one's homeland is the most important task of a patriot and this narrative tries to emphasize it, by stressing that the heroes were all ready to sacrifice their lives for Katya. "A war to save Russian Civilization" incorporates the nationalist viewpoint as well as the feeling of superiority over other nations due to Russia's long cultural heritage. This serves to unify all previous regimes with the help of culture and religion.

The connections with Western cinema showed the important features of the Second World War that the filmmakers included to meet the needs of the contemporary viewer, as 
well as stating the modernization of Russian cinema. Modernization on the other hand is also connected with fostering patriotism in the contemporary Russia, one of the goals of the state and people, is to show that the country is advanced enough and can compete with other, mainly Western, powers.

The Western Second World War narratives have also influenced Russian cultural memory through Hollywood or European blockbusters. The analysis emphasizes that Stalingrad has a dialog with these films, by either contesting some narratives or incorporating others. The intertextuality with the films A Woman in Berlin, Pearl Harbor and Jewish narratives, is designed to introduce the Russian perspective to the world. The American patriotic narrative and heroic achievements also justify Russian patriotism, since they both are considered to be the winners of the Second World War.

In addition to the narratives, it was also important to explain how the film tries to influence cultural memory through technology. There are conscious choices made to give the audience the sense of "being there" and "experiencing" the war by screening it in 3D cinema. The story is made even more emotional by adding appropriate melodramatic music and special effects. The structure of the narrative showed that it is simple and easy to follow. The reception showed that overall, the feedback to the film was very positive among ordinary viewers, those who paid attention mainly to the technological side and to the story, thus, proving that the film producers knew what to offer for the target group.

All in all, the film Stalingrad was a 2013 blockbuster, which means that people consider the war memory important and saw film as an appropriate way to portray it. The fact that the Second World War for contemporary Russians is so strongly connected with Orthodox religion shows that cultural memory of Russians unites the Soviet era war with the Old Russian culture. The commemoration of the dead has always been connected with the 
church, and even if religion was purposefully undermined during the Soviet era, the official narrative still needed to give explanations for the suffering and sacrifices through "a holy war" prism. This is the reason why contemporaries think the Orthodox Church was also present during the war, and why it is not conflicting with cultural memory. Here, no one stresses that the war is not portrayed "accurately," since it seems to be appropriate to incorporate religious symbols instead of the Soviet ones.

The Battle of Stalingrad has been a popular topic for war movies and literature since the end of the Second World War. Moreover, the Second World War is a very important part of nation-building, identity and memory not only in the Soviet Union and contemporary Russia. It has played its own part in other countries that participated in the war. It is important to note that contemporary Russia is not the only country where the war arouses patriotic feelings and sense of pride. This can be similarly found, for instance, in movies made in the US. The case of Stalingrad shows that the topic is still very important nowadays, since the film producers made an effort to get the attention, by using the new technology or by choosing the location of the premier in Volgograd.

From the perspective of cultural memory, one has to acknowledge that the film is a medium for both reinstating old and for creating new cultural memory, as well as a product of cultural memory. The film was supported by the state and can therefore also be seen as a tool for fostering "official" memory of the war, as well as for creating national identity and patriotism on the basis of the Second World War victory. In addition, the film is also a product of individuals, who express their own world views and concerns through their work. Stalingrad as a commercial product, on the other hand, needs to have viewers in order to influence the society, thus the emotional involvement of the audience as well as popularity of the film are in fact stating the effectiveness of the medium and the importance of the topic. 


\section{BIBLIOGRAPHY}

Abbenhuis, Maartje. An Age of Neutrals: Great Power Politics, 1815-1914. Cambridge: Cambridge University Press, 2014.

Allen, Graham. Intertextuality. New York, Abingdon: Routledge, 2011.

Anderson, Benedict. Imagined Communities Reflections on the Origin and Spread of Nationalism. London: Verso, 1983.

Assmann, Jan. "Collective Memory and Cultural Identity." New German Critique, no. 65 (1995): 12533.

Religion and Cultural Memory: Ten Studies. Stanford, CA: Stanford University Press, 2006.

Barker, Chris. Cultural Studies: Theory and Practice. 2nd ed. London, Thousand Oaks, New Delhi: SAGE, 2005.

Barthes, Roland. Elements of Semiology. Translated by Annette Lavers and Colin Smith. New York: Hill and Wang, 1977.

."Myth Today." In Media and Cultural Studies: Keyworks, edited by Meenakshi Gigi Durham and Douglas M. Kellner, 100-106. Hoboken: John Wiley \& Sons, 2009.

Beumers, Birgit. Directory of World Cinema : Russia. Bristol: Intellect Ltd., 2010.

Boltz, Marilyn G. "The Cognitive Processing of Film and Musical Soundtracks." Memory \& Cognition, 32 (7), 2004, 1194-1205.

Bordwell, David. On the History of Film Style. Harvard University Press, 1997.

Brandenberger, David. National Bolshevism: Stalinist Mass Culture and the Formation of Modern Russian National Identity, 1931-1956. Cambridge, Massachusetts, London: Harvard University Press, 2002.

"Stalin, the Leningrad Affair, and the Limits of Postwar Russocentrism." Russian Review, 2, 2004, 241-55.

Cantril, Hadley. "Review of 'Motion Pictures and Youth: A Summary' and 'Getting Ideas from the Movies." The Journal of Abnormal and Social Psychology 29, no. 2 (July 1934): 238-39.

Carleton, Gregory. "Victory in Death: Annihilation Narratives in Russia Today." History \& Memory 22, no. 1 (2010): 135-68.

Carretero, Mario. Constructing Patriotism: Teaching History and Memories in Global Worlds. IAP, 2011.

Chatman, Seymour B. Story and Discourse: Narrative Structure in Fiction and Film. Ithaca and London: Cornell University Press, 1980.

Cohen, Annabel J. "Film Music and the Unfolding Narrative." In Language, Music, and the Brain, Vol. 10. Strüngmann Forum Reports. Cambridge, MA: MIT Press, 2013.

Dennett, Daniel C., and Chris Westbury. "Mining The Past To Construct The Future: Memory and Belief as Forms of Knowledge." In Memory, Brain, and Belief, 11-32. Harvard Univ Pr, 2000.

Dijk, Teun A. van. "Critical Discourse Analysis." In The Handbook of Discourse Analysis, edited by Deborah Schiffrin, Deborah Tannen, and Heidi E. Hamilton, 352-71. Malden, Oxford: Blackwell Publishers Inc., 2001.

- Discourse Studies: A Multidisciplinary Introduction. 2nd ed. Los Angeles, London, New Delhi, Singapore, Washington DC: SAGE Publications Ltd, 2011.

Dobrenko, Evgeny. "Utopias of Return: Notes on (Post-)Soviet Culture and Its Frustrated (Post)Modernisation." Studies in East European Thought 63, no. 2 (2011): 159-71.

Ebbrecht, Tobias. "History, Public Memory and Media Event." Media History 13, no. 2-3 (2007): 221-34.

Edgerton, Gary R., and Peter C. Rollins, eds. Television Histories: Shaping Collective Memory in the Media Age. Lexington: University Press of Kentucky, 2001.

Elsaesser, Thomas, and Warren Buckl. Studying Contemporary American Film - A Guide To Movie Analysis. New York: Oxford University Press Inc., 2002.

Emden, Christian, and David R. Midgley. Cultural Memory and Historical Consciousness in the German-Speaking World Since 1500: Papers from the Conference "The Fragile Tradition", Cambridge 2002. Peter Lang, 2004. 
Erll, Astrid, and Ansgar Nünning, eds. Media and Cultural Memory : Cultural Memory Studies : An International and Interdisciplinary Handbook. Berlin, DEU: Walter de Gruyter, 2008.

Fairclough, Norman. Analysing Discourse: Textual Analysis for Social Research. London: Routledge, 2003.

Frye, Northrop. Northrop Frye on Religion: Excluding The Great Code and Words with Power. Toronto: University of Toronto Press, 2000.

. The Great Code: The Bible and Literature. Toronto: University of Toronto Press, 2006.

Halbwachs, Maurice. On Collective Memory. Chicago: University of Chicago Press, 1992.

Hall, Stuart. "Encoding/decoding." In Media and Cultural Studies: Keyworks, edited by Meenakshi Gigi Durham and Douglas M. Kellner, 163-73. John Wiley \& Sons, 2009.

Harris, Erika. Nationalism: Theories and Cases. Edinburgh, GBR: Edinburgh University Press, 2009.

Hasenmueller, Christine. "Panofsky, Iconography, and Semiotics." The Journal of Aesthetics and Art Criticism 36, no. 3 (April 1, 1978): 289-301.

Hew, Khe Foon, and Wing Sum Cheung. "Use of Three-Dimensional (3-D) Immersive Virtual Worlds in K-12 and Higher Education Settings: A Review of the Research." British Journal of Educational Technology 41, no. 1 (January 1, 2010): 33-55.

Hobsbawm, Eric, and Terence O. Ranger, eds. The Invention of Tradition. Cambridge: Cambridge University Press, 1992.

Hoeckner, Berthold, Emma W. Wyatt, Jean Decety, and Howard Nusbaum. "Film Music Influences How Viewers Relate to Movie Characters." Psychology of Aesthetics, Creativity, and the Arts 5, no. 2 (May 2011): 146-53.

Jaworski, Adam, and Nikolas Coupland. The Discourse Reader. 2nd ed. London, New York: Routledge, 1999.

Jedlowski, Paolo. "Memory and Sociology: Themes and Issues." Time \& Society 10, no. 1 (March 1, 2001): 29-44.

Jørgensen, Marianne W., and Louise J. Phillips. Discourse Analysis as Theory and Method. London, Thousand Oaks, New Delhi: SAGE Publications Ltd, 2002.

Kaes, Anton. "History and Film: Public Memory in the Age of Electronic Dissemination." History and Memory 2, no. 1 (Fall 1990): 111-29.

Kelman, Herbert C. "Nationalism, Patriotism, and National Identity: Social-Psychological Dimensions." In D. Bar-Tal \& E. Staub (Eds.), Patriotism in the Life of Individuals and Nations, 165-89. Chicago: Nelson-Hall, 1997.

Kilbourn, Russell J. A. Cinema, Memory, Modernity: The Representation of Memory from the Art Film to Transnational Cinema. Routledge Advances in Film Studies 6. New York: Routledge, 2010.

Kirschenbaum, Lisa A. “'Our City, Our Hearths, Our Families': Local Loyalties and Private Life in Soviet World War II Propaganda." Slavic Review 59, no. 4 (December 1, 2000): 825-47.

Kudryashov, Sergei. "Remembering and Researching the War: The Soviet and Russian Experience." In Experience and Memory: The Second World War in Europe, 86-115. New York, Oxford: Berghahn, 2010.

La Bar, Kevin S., and Roberto Cabeza. "Cognitive Neuroscience of Emotional Memory." Nature Reviews Neuroscience 7, no. 1 (January 2006): 54-64.

Laruelle, Marlene, ed. Russian Nationalism and the National Reassertion of Russia. New York: Routledge, 2009.

Lehti, Marko, and David J. Smith, eds. Post-Cold War Identity Politics: Northern and Baltic Experiences. London: Routledge, 2004.

Lotman, Juri. Culture and Explosion. Edited by Marina Grishakova. 1 edition. Berlin; New York: Mouton de Gruyter, 2009.

Kultuurisemiootika (In English: Semiotics of Culture). Tallinn: Olion, 1999.

Kunstilise teksti struktuur (In English: The Structure of the Artistic Text). Tallinn: Tänapäev, 2006.

- The Unpredictable Workings of Culture. 1st edition. Tallinn: Tallinn University Press, 2013.

Macnab, Geoffrey. "Stalingrad 3D, Film Review: Visual Dynamism and Plenty of Pedigree." The Independent, February 20, 2014. http://www.independent.co.uk/arts- 
entertainment/films/reviews/stalingrad-3d-film-review-visual-dynamism-and-plenty-ofpedigree-9142491.html.

Majstorović, Danijela, and Inger Lassen. Living with Patriarchy: Discursive Constructions of Gendered Subjects Across Cultures. Amsterdam, Philadelphia: John Benjamins Publishing, 2011.

Mazierska, Ewa. European Cinema and Intertextuality: History, Memory and Politics. Basingstoke, Hampshire [UK]; New York: Palgrave Macmillan, 2011.

Merridale, Catherine. Ivan's War: Life and Death in the Red Army, 1939-1945. New York: Macmillan, 2006.

Mihkelev, Anneli. We Have Something In Common: The Baltic Memory. Collegium Litterarum 21. Tallinn: Underi ja Tuglase Kirjanduskeskus, 2007.

Mikhaleva, Galina. "Overcoming the Totalitarian Past: Foreign Experience and Russian Problems." Russian Politics and Law 48, no. 1 (August 2010).

Nora, Pierre. "Between Memory and History: Les Lieux de Mémoire." Representations, no. 26 (April 1, 1989): 7-24.

Norris, Stephen M. Blockbuster History in the New Russia : Movies, Memory, and Patriotism. Bloomington, IN: Indiana University Press, 2012.

"Packaging the Past: Cinema and Nationhood in the Putin Era." KinoKultura, 2008. http://www.kinokultura.com/2008/21-norris.shtml.

Pääbo, Heiko. Potential of Collective Memory Based International Identity Conflicts in Post-Imperial Space: Comparison of Russian Master Narrative with Estonian, Ukrainian and Georgian Master Narratives. PhD diss., Tartu University Press, 2011.

Palat, Madhavan K., ed. Social Identities in Revolutionary Russia. Basingstoke: Palgrave Macmillan, 2001.

Panofsky, Erwin. "Reflections on Historical Time." Critical Inquiry 30, no. 4 (Summer 2004): 691701.

"Studies in Iconology." In Images: A Reader, edited by Sunil Manghani, Arthur Piper, and Jon Simons, 86-89. London, Thousand Oaks, New Delhi: SAGE, 2006. "Style and Medium in the Motion Pictures." In Film Theory and Criticism, edited by Gerald Mast and Marshall Cohen, 215-33. New York: Oxford University Press, 1985.

Primoratz, Igor, and Aleksandar Pavkovic. Patriotism : Philosophical and Political Perspectives. Abingdon, Oxon, GBR: Ashgate Publishing Group, 2008.

Radstone, Susannah, and Bill Schwatz, eds. Memory: Histories, Theories, Debates. New York: Fordham University Press, 2010.

Rooney, Brendan, and Eilis Hennessy. "Actually in the Cinema: A Field Study Comparing Real 3D and 2D Movie Patrons' Attention, Emotion, and Film Satisfaction." Media Psychology 16, no. 4 (October 1, 2013): 441-60.

Rosenstone, Robert A. "History in Images/History in Words: Reflections on the Possibility of Really Putting History onto Film." The American Historical Review 93, no. 5 (December 1, 1988): 1173-85.

Saussure, Ferdinand De. Course in General Linguistics. Translated by Wade Baskin. New York: The Philosophical Library, inc., 1959.

Schlauch, Margaret. "Russian People's Wars in 1812 and 1941—Recent Soviet Historiography." Science \& Society 6, no. 1 (January 1, 1942): 24-33.

Smith, Anthony D. "Chosen Peoples: Why Ethnic Groups Survive." Ethnic \& Racial Studies 15, no. 3 (July 1992): 436.

- Ethno-Symbolism and Nationalism: A Cultural Approach. New York, Oxon: Routledge, 2009.

- National Identity. Reno: University of Nevada Press, 1991.

Smith, Kathleen E. Mythmaking in the New Russia: Politics and Memory during the Yeltsin Era. Ithaca: Cornell University Press, 2002.

"Study Center Vasily Grossman | История Рукописи." Accessed December 3, 2014. http://grossmanweb.eu/?page_id=413\&lang=ru.

Sturken, Marita, and Lisa Cartwright. Practices of Looking: An Introduction to Visual Culture. Oxford; New York: Oxford University Press, 2001. 
Taylor, Richard. Film Propaganda: Soviet Russia and Nazi Germany. London, New York: I.B.Tauris, 1998.

Toshchenko, Zhan T. "Historical Consciousness and Historical Memory: An Analysis of the Current Situation." Russian Studies in History 49, no. 1 (Summer 2010).

Turmakin, Nina. "Myth and Memory in Soviet Society." Society 24, no. 6 (1987): 69-72.

Van Damme, Ilse, and Karolien Smets. "The Power of Emotion versus the Power of Suggestion: Memory for Emotional Events in the Misinformation Paradigm." Emotion 14, no. 2 (April 2014): 310-20.

Wertsch, James V. Voices of Collective Remembering. New York: Cambridge University Press, 2002.

White, Hayden. "Historiography and Historiophoty." The American Historical Review 93, no. 5 (December 1, 1988): 1193-99.

Winter, Jay, and Emmanuel Sivan. War and Remembrance in the Twentieth Century. Cambridge, New York, Melbourne: Cambridge University Press, 2000.

Wood, Elizabeth A. "Performing Memory: Vladimir Putin and the Celebration of WWII in Russia." The Soviet and Post-Soviet Review, no. 38 (2011).

Youngblood, Denise J. Russian War Films: On the Cinema Front, 1914-2005. Lawrence: University Press of Kansas, 2007.

“9 Мая Состоится Телепремьера Фильма Федора Бондарчука 'Сталинград’ (In English: The Premier of Fedor Bondarchuk's Film 'Stalingrad' on TV Will Take Place on May 9).” Российская Газета, Маy 8, 2014. http://www.rg.ru/2014/05/08/stalingrad.html.

Апрелев, Роман. “Фильм «Сталинград» Играет На Одном Поле С «Человеком-Пауком» (In English: Film 'Stalingrad' Plays on the Same Field with 'Spiderman')," October 14, 2013. http://www.vlg.aif.ru/culture/art/946542.

Архангельский, Андрей. “Приказано Выжать (In English: Ordered to Squeeze It Out).” Искусство Кино, November 2013. http://kinoart.ru/ru/archive/2013/11/prikazano-vyzhat.

Афанасьева, А.И., and В.И. Меркушин. "Великая Отечественная Война В Исторической Памяти Россиян (In English: Great Patriotic War in the Historicla Memory of Russians).”

Соииологические Исследования, 2005, 11-22.

Афанасьев, Иван. Дом Солдатской Славы (In English House of Soldier's Glory). Москва: ДОСААФ, 1970.

“Владимир Мединский Озвучил Результаты Работы По Поддержке Отечественного Кинематографа (in English: Vladimir Medisnki Announced the Results of the Support for Domestic Cinema).” Министерство Культуры Российской Федерации, December 2, 2014. http://mkrf.ru/press-tsentr/novosti/ministerstvo/vladimir-medinskiy-ozvuchil-rezultaty-rabotypo-podderzhke-otechestvennogo-kinem.

“Волгоградские Ветераны Поставили 'Четверку' Фильму ‘Сталинград’ (In English: The Veterans in Volgograd Gave 'Grade Four (B)' to the Film Stalingrad).” РИА Новости, September 28, 2013. http://ria.ru/culture/20130928/966517900.html.

Гроссман, Василий. Жизнь И Судьба (In English Life and Fate). 2nd ed. Таллинн: Ээсти Раамат, 1990.

Добренко, Евгения. Метафора Власти. Литература Сталинской Эпохи В Историческом Освещении (In English: Metaphor of Power: Literature of the Stalin Era in Historical Context). München: Verlag Otto Sagner, 1993.

“Дума единогласно приняла закон против оправдания нацизма (In English: The Duma Unanimously Passed a Law Against Justification of Nazism).” BBC Russian, April 4, 2014. http://www.bbc.co.uk/russian/russia/2014/04/140404_nazism_duma_punishment.shtml.

"Итоги Года: Люди, Программы, Фильмы (In English: Results of the Year: People, Programmes, Films).” ВЦИОМ, December 26, 2013. http://wciom.ru/index.php?id=459\&uid=114659.

“Какие Из Этих Фильмов Вы Порекомендовали Бы Посмотреть Своим Родственникам, Друзьям, Знакомым? (In English: Which of These Films Would You Recommend to Your Relatives, Friends and Aquintences?)." ВЦИОМ, June 8, 2014. http://wciom.ru/zh/print_q.php?s_id=966\&q_id=66429\&date=08.06.2014.

“КиноПоиск." Accessed April 9, 2015. http://www.kinopoisk.ru/film/468196/press/.

Лотман, Юрий. Семиотика Кино И Проблемы Киноэстетики (In English: Semiotics of Cinema and Problems of Cinema Aesthetics). Таллин: Ээсти Раамат, 1973. 
“Лучшая Телепередача, Телесериал И Кинофильм 2013 Года (In English: The Best TV Programme, TV Series and Film in Year 2013).” Levada, February 11, 2014. http://www.levada.ru/11-02-2014/luchshaya-teleperedacha-teleserial-i-kinofilm-2013-goda.

“Мегакритик." Accessed April 9, 2015. http://www.megacritic.ru/film/2395.html.

Мединский, Владимир. Война. Мифы ССCP. 1939-1945 (In English: War. Myths of USSR. 19391945). 2nd ed. ОЛМА Медиа Групп, 2011.

"На Заседании Совбеза Украинский Чиновник Оскорбил Память Жертв Второй Мировой (In English: On the Security Council Meeting a Ukrainian Official Insulted the Memory of the Second World War Victims)." Vesti, March 4, 2014. http://www.vesti.ru/doc.html?id=1345803.

“О Внесении Изменений В Уголовный Кодекс Российской Федерации И В Статью 151 Уголовно-Процессуального Кодекса Российской Федерации (по Вопросу Установления Уголовной Ответственности За Посягательство На Историческую Память В Отношении Событий, Имевших Место В Период Второй Мировой Войны) (In English: On Amendments to the Criminal Code of the Russian Federation and Article 151 of the Criminal Procedure Code of the Russian Federation (on the Criminalization of Encroachment on Historical Memory in Relation to the Events That Took Place during the Second World War)." Законопроект № 197582-5. Accessed April 18, 2014. http://asozd2.duma.gov.ru/main.nsf/\%28SpravkaNew\%29?OpenAgent\&RN=197582-5\&02, .

“О Комиссии При Президенте Российской Федерации По Противодействию Попыткам Фальсификации Истории В Ущерб Интересам России (In English: On the Presidential Commission for Countering the Attemts to Falsify History in Order to Harm Russian Interests)." Указ Президента Российской Федерации от 15 мая 2009 г. N 549. Accessed April 25, 2014. http://www.rg.ru/2009/05/20/komissia-dok.html.

“О Противодействии Попыткам Фальсификации Истории Народов В Ущерб Интересам России (In English: Countering the Attempts to Falsify Nation's History in Order to Harm Russian Interests)," November 19, 2012. http://council.gov.ru/activity/activities/roundtables/30331.

“Почему В Украине «запретили» «Белую Гвардию»? (In English: Why Was the White Guard Banned in Ukraine?” Зеркало Недели | Дзеркало Тижня| Mirror Weekly. Accessed December 1, 2014.

http://gazeta.zn.ua/CULTURE/pochemu_v_ukraine_zapretili_beluyu_gvardiyu_.html.

“Президент Открыл Легендарный Сталинградский Фонтан ‘Детский Хоровод’ (In English: President Opened the Legendary Fountain 'Dancing Children').” Российская Газета, August 23, 2013. http://www.rg.ru/2013/08/23/pamiatnik-site.html.

“Путин Открыл Воссозданный Фонтан ‘Детский Хоровод’ В Волгограде (In English: Putin Opened the Restored Fountain 'Dancing Children.”” РИА Новости, August 23, 2013. http://ria.ru/society/20130823/958164742.html.

Савельев, Лев. Дом Павлова (In English: Pavlov's House). Москва: Советская Россия, 1970.

- Дом Сержанта Павлова (In English: Sergeant Pavlov's House). Москва: Военное Издательство, 1960.

Сидорчик, Андрей. "Сталинград. Охота На Оскара (In English: Stalingrad. Hunt for Oscars).” Аргументы И Фактыл, November 10, 2013. http://www.aif.ru/opinion/945317.

Талавер, Александра. "Память О Великой Отечественной Войне В Постсоветском Кинематографе (In English: Memory of the Great Patriotic War in Post-Soviet Cinema).” Философия И Исследования Культуры, Этапы осмысления прошлого (от 1990-х к 2000м, Т16 (2013).

“Телеканал 'Дождь' под угрозой прекращения вещания (In English: Channel Rain is Under a Threat of Closing)." BBC Russian, January 29, 2014. http://www.bbc.co.uk/russian/russia/2014/01/140129_tv_rain_conflict.shtml.

Трофименков, Михаил. “Искупительные Хроники 'Безымянная - Одна Женщина В Берлине' И Другая Новая Правда О Войне (In English: Redemptive Chronicles Anonymous -A Woman in Berlin and the Other New Truth about the War)." Коммерсант, June 19, 2009. http://www.kommersant.ru/pda/kommersant.html?id=1185828.

“Фильмом Года Названа Работа Российского Режиссера Ф. Бондарчука «Сталинград» (In English: F. Bondarchuk's 'Stalingrad' Is the Film of the Year ).” ВЦИОМ: Итоги Года: 
Люди, Программьи, Фильмьи, December 26, 2013.

http://wciom.ru/index.php?id=459\&uid=114659.

“Фильм Федора Бондарчука «Сталинград» - Рецензия И Отзыв (In English: Fyodor Bodanrchuk’s Film Stalingrad - Reviews and Feedback)." Собака, September 23, 2013.

http://www.sobaka.ru/rnd/city/cinema/18403.

“Харьков, Донецк И Одесса Поднимают Российские Флаги (In English: Harkhov, Donetsk, Odessa Are Raising Russian Flags)." Vesti, March 3, 2014. http://www.vesti.ru/doc.html?id=1342664.

Швечиков, Алексей, ed. Православие И Патриотизм (In English: Orthodoxy and Patriotism). Санкт Петербург: Алетейя, 2005.

Шпагин, Александр. Великая Отечественная Война В Российском Кинематографе (In English: The Great Patriotic War in Russian Cinematography). Телеканал “Дождь,” 2012. http://tvrain.ru/articles/aleksandr_shpagin_velikaya_otechestvennaya_voyna_v_rossiyskom_ki nematografe-243935/.

\section{FILMOGRAPHY}

A Woman in Berlin (Anonyma - Eine Frau in Berlin). Directed by: Max Färberböck. Written by: Anonymous. 2008.

Enemy at the Gates. Directed by: Jean-Jacques Annaud. Written by: Jean-Jacques Annaud, Alain Godard. 2001.

Pearl Harbor. Directed by: Michael Bay. Written by: Randall Wallace. 2001.

Rainbow (Paдyza). Directed by: Mark Donskoy. (1943).

Stalingrad (Сталинград). Directed by: Yuri Ozerov. Written by: Yuri Ozerov. 1990 (1990).

Stalingrad (Сталинград). Director: Fedor Bondarchuk. Written by: Ilya Tilkin and Sergey Snezhkin. 2013.

The Turning Point (Великий перелом). Director: Fridrikh Ermler. Written by: Boris Chirskov. 1945.

The Hot Snow (Горячий снег). Director: Gavriil Egiazarov (Yegiazarov). Written by: Yuri Bondarev. 1972. 